\title{
COMPARING THE INCIDENCE OF TAXES AND SOCIAL SPENDING IN BRAZIL AND THE UNITED STATES
}

Sean Higgins, Nora Lustig, Whitney Ruble and Timothy Smeeding

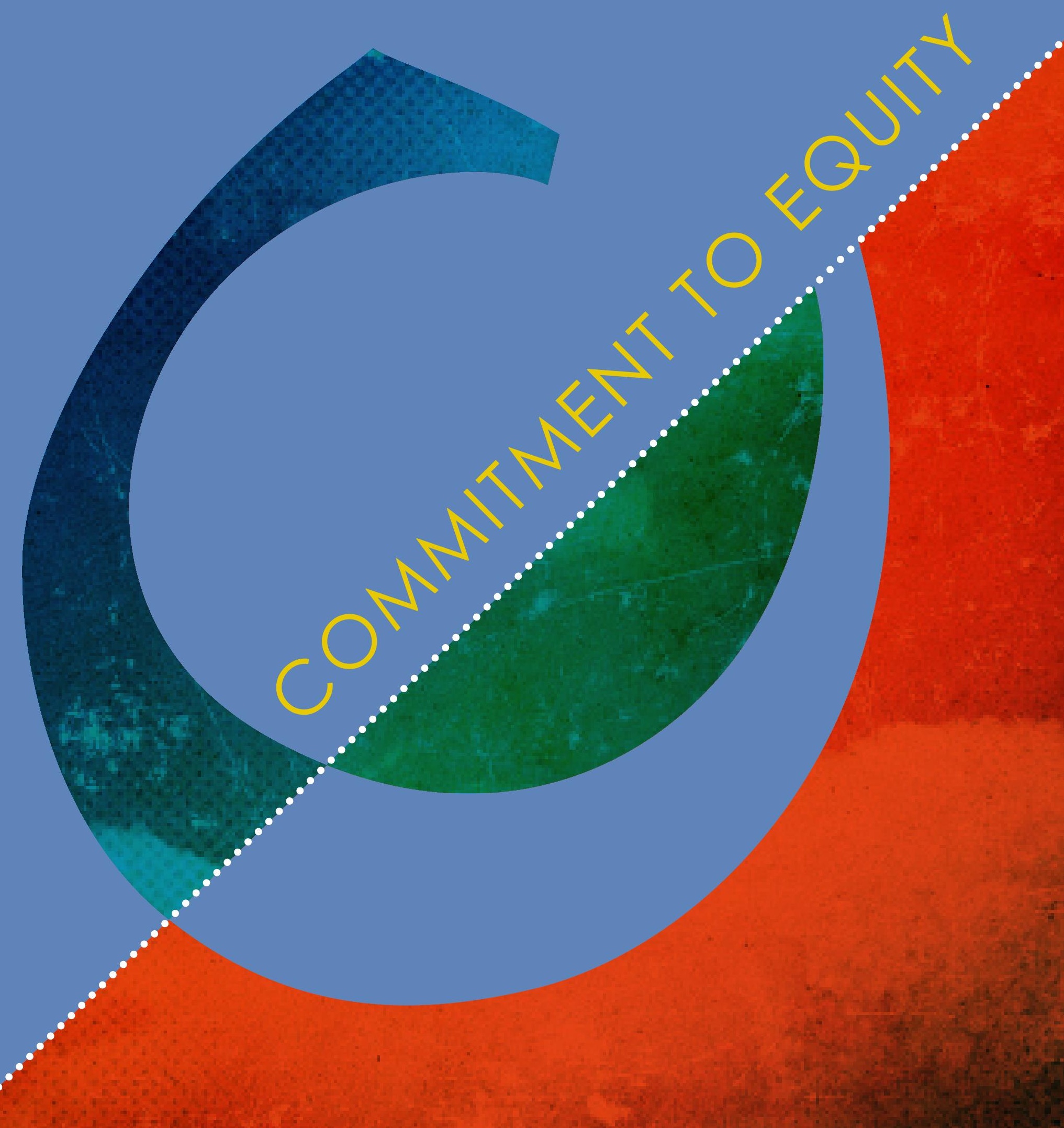


COMMITMENT TO EQUITY

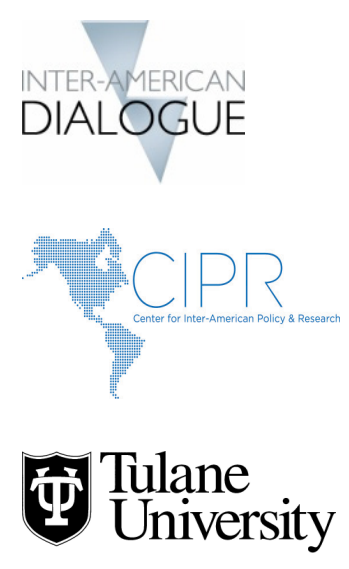

COMPARING THE INCIDENCE OF TAXES AND SOCIAL SPENDING IN BRAZIL AND THE UNITED STATES*

Sean Higgins, ${ }^{a}$ Nora Lustig, ${ }^{b}$ Whitney Ruble and Timothy Smeeding ${ }^{c}$

CEQ Working Paper No 16

NOVEMBER 30, 2013

${ }^{a}$ Ph.D. Student, Department of Economics, Tulane University

b Samuel Z. Stone Professor of Latin American Economics, Tulane University; Nonresident Fellow, Center for Global Development and Inter-American Dialogue

c Director, Institute for Research on Poverty; Arts and Sciences Distinguished Professor of Public Affairs and Economics, University of Wisconsin at Madison

\section{ABSTRACT}

We perform the first comprehensive fiscal incidence analyses in Brazil and the US, including direct cash and food transfers, targeted housing and heating subsidies, public spending on education and health, and personal income, payroll, corporate income, property, and expenditure taxes. In both countries, primary spending is close to 40 percent of GDP. The US achieves higher redistribution through direct taxes and transfers, primarily due to underutilization of the personal income tax in Brazil and the fact that Brazil's highly progressive cash and food transfer programs are small while larger transfer programs are less progressive. However, when health and non-tertiary education spending are added to income using the government cost approach, the two countries achieve similar levels of redistribution. This result may be a reflection of better-off households in Brazil opting out of public services due to quality concerns rather than a result of government effort to make spending more equitable.

Keywords: inequality, fiscal policy, taxation, social spending

JEL: D31, H22, I38

\footnotetext{
* The authors are grateful to Luis Felipe López-Calva for providing very helpful comments as discussant of an earlier version of this paper, to seminar participants for useful comments and suggestions, to Claudiney Pereira for collaboration on the Brazil analysis, to Grant Driessen for collaboration on the US analysis, and to Adam Ratzlaff and David Roberts for research assistance. This paper is part of the Commitment to Equity (CEQ) project. Led by Nora Lustig, CEQ is designed to analyze the impact of taxes and social spending on inequality and poverty, and to provide a roadmap for governments, multilateral institutions, and nongovernmental organizations in their efforts to build more equitable societies (www.commitmenttoequity.org). The paper does not necessarily reflect the opinions of the institutes and universities where the authors are employed or affiliated.
} 


\section{INTRODUCTION}

How much do the Western Hemisphere's two largest economies and most populous countries redistribute through social spending and taxes? Although the United States has an income per capita four times as large as Brazil's, the countries share similarities that make this comparison interesting. In terms of government size, the two countries are similar, with combined primary spending by federal, state, and local governments close to 40 percent of GDP in both countries. ${ }^{1}$ The two countries each have high levels of economic inequality relative to their level of development; furthermore, when the US had a GDP per capita similar to Brazil's today, its level of inequality was similar to that observed in Brazil today (Plotnick et al., 1998). In both countries, one key determinant of income inequality is the unequal distribution of human capital associated with high rates of school incompletion and, to some extent, race (Goldin and Katz, 2008, Nopo, 2012).

Both countries also have high inequality of opportunity (Brunori et al., 2013), low levels of intergenerational mobility (Jäntti et al., 2006, Corak, 2013), and a fairly similar profile with respect to income polarization (Ferreira et al., 2013, figure F5.1C). Although Brazil has higher levels of income inequality and intergenerational earnings and education persistence than the US, these measures are rising in the US (Aaronson and Mazumder, 2008, Kenworthy and Smeeding, forthcoming) and moving in the opposite direction in Brazil (Ferreira et al., 2013, Lustig et al., 2013b). If trends continue, their levels could converge.

Based largely on Lustig and Higgins' (2013) methodology, we perform comprehensive fiscal incidence analyses to measure the impact of public spending and taxation on inequality in the two countries. Our analysis includes direct cash and food transfers, direct personal income, payroll, corporate income, and property taxes, indirect expenditure taxes, indirect subsidies for energy and housing, and spending on government-provided health and non-tertiary education. Our primary data sources are the 2011 Current Population Survey (CPS) for the US and the 2008-2009 Pesquisa de Orçamentos Familiares (POF) for Brazil; these are supplemented by the 2011 American Community Survey (ACS), 2011 American Housing Survey (AHS), and 2007 National Household Education Survey (NHES) in the US, and the 2008 Pesquisa Nacional por Amostra de Domicílios (PNAD) in Brazil.

Our study is the only comprehensive incidence analysis we are aware of for the United States for a relatively recent year. Other available studies for the United States usually omit indirect taxes and public spending on education and health (e.g., Kim and Lambert, 2009). The one study we are aware of that includes both indirect taxes and these in-kind benefits (Garfinkel et al., 2006) uses data from 2000. In addition, we include imputed rent for owner-occupied housing, which is omitted from most studies on the US despite being an important component of income for the elderly (Bradbury, 2013).

\footnotetext{
${ }^{1}$ Brazil's consolidated primary spending (total spending minus interest payments) was 41.4 percent of GDP in 2009 (Ministério da Fazenda, 2010a), while it was 38.6 percent of GDP in the US in 2011 (International Monetary Fund, 2013, table 4a).
} 
In the areas of allocating taxes and public spending on health and education, our study uses more robust methodologies than did earlier authors. For example, we use microsimulation results that take into account the fact that different states in the US have vastly different excise and property tax mixes_-some much more regressive than others (Newman and O'Brien, 2011). For health and education spending, we use data on Medicare and Medicaid coverage to determine the distribution of health benefits, and use multiple household surveys to determine the distribution of education benefits given the lack of data on public vs. private school attendance in our main survey.

In the case of Brazil, we build on the comprehensive incidence analysis undertaken by Higgins and Pereira (forthcoming). The main differences are that here we use a revised methodology described in Lustig and Higgins (2013) when imputing public spending on education and health, include the corporate income tax, and use square root scale equivalized income rather than household per capita income (with household per capita results available in the online supplement). We also exclude tertiary education spending — which was included in Higgins and Pereira (forthcoming) — to maintain comparability with the US, where it was not possible to determine beneficiaries of public tertiary education spending. ${ }^{2}$

Another contribution of our paper is to compare the redistributive effects of the revenue collection and social spending systems in the two countries, which leads us to a number of new insights. Direct comparisons between the two countries are rare; Bourguignon et al. (2008) decompose differences in the household income distributions in the two countries, but the only component of government spending and taxation they analyze is direct transfers. Multi-country studies that include both the US and Brazil similarly tend to overlook subsidies, expenditure taxes, and/or public spending on health and education. When public spending on education and health is included in the analysis, Brazil is one of the most redistributive Latin American countries, ${ }^{3}$ while the US remains less redistributive than other high-income countries (Garfinkel et al., 2006). With Brazil leading the less-redistributive Latin American countries and the US lagging the more-redistributive high-income countries, this makes the analysis even more interesting.

Before adding government spending in health and education to income, Brazil achieves significantly less redistribution than the US. This is due to a combination of factors: Brazil's direct taxes are both considerably smaller as a percent of GDP and considerably less progressive than those in the US, Brazil's highly progressive direct transfer programs are small while its larger direct transfer programs

2 Public tertiary education spending is $0.8 \%$ of GDP in Brazil. Because tertiary education spending is almost distributionally neutral, with a concentration coefficient close to the market income Gini, its exclusion does not significantly affect results. In the case of the US, no estimates exist of the distribution of public tertiary spending benefits. Nevertheless, it is a relatively small spending item, and therefore we also expect it to have a minimal impact on results.

3 This comparison is based on data from Lustig and Pessino (forthcoming) for Argentina, Paz Arauco et al. (forthcoming) for Bolivia, Higgins and Pereira (forthcoming) for Brazil, Contreras and Ruiz-Tagle (2013) for Chile, Melendez (2013) for Colombia, Sauma and Trejos (2013) for Costa Rica, Cabrera et al. (2013) for Guatemala, Scott (forthcoming) for Mexico, Higgins et al. (2013) for Paraguay, Jaramillo (forthcoming) for Peru, and Bucheli et al. (forthcoming) for Uruguay. 
are less progressive, and Brazil begins with a more unequal market income distribution (which could in turn be the result of its smaller transfer system in the past).

When government spending in health and education are included, the two countries reduce inequality by approximately the same amount. This result must be analyzed with caution for numerous reasons. First, the middle and upper classes might opt out of public education and health services due to quality concerns (Ferreira et al., 2013) which would inflate inequality reduction. Second, spending amounts do not necessarily reflect quality (which comes into play in both the US with respect to inflated healthcare costs and in Brazil with respect to low quality services). Third, although we account for differences in per student spending by state, using state spending averages still overlooks the large intrastate variations of spending across localities and the fact that-unlike other OECD countries - the US spends less on students from disadvantaged backgrounds than on other students (OECD, 2011b).

Additional caveats are in order before comparing the incidence of social spending and taxation in the two countries. Although the implementation of a consistent methodology aspires to achieve a high degree of comparability, survey differences can compromise this comparability. The sampling between the two primary surveys differ, such that POF is representative at the state level but CPS is not; the latter fact means our estimations of consumption and property taxes in the US-which take into account the largely different tax mixes of each state-are imperfect. The survey designs also differ: in the case of imputed rent for owner occupied housing, for example, POF asks owner occupiers how much their dwelling would be rented for if it were rented, while CPS only identifies who owns their home and even lacks data on rates paid by renters (which rules out the usual regression technique to predict imputed rent). Thus, we follow the methodology of Short and O'Hara (2008) which involves predicting rental rates using a matching technique with the AHS. In addition to survey differences, as a developing country Brazil faces many obstacles to revenue collection and redistribution not faced by the US, such as a large informal sector.

By restricting our analysis to taxation and social spending, we overlook government spending on public sector wages. Although higher public sector employment is associated with lower inequality on a global level (Milanović, 1994), public sector wages are regressive in Brazil (Medeiros and Souza, 2013). Public servants in both countries earn a wage premium over comparable private sector workers. In Brazil, this premium has been increasing over time (Souza and Medeiros, 2013), while it has been decreasing in the US (Borjas, 2002); in addition, the levels and trends of the public-private wage differential differ substantially by education level (Poterba and Rueben, 1994, Braga et al., 2009). Our analysis makes no attempt to capture this aspect of public spending, which could dampen the redistributive impact of the state.

Without forgetting these caveats, the paper proceeds as follows. The next section provides more detail about taxation and social spending in the two countries, and provides evidence of their potentially converging inequality levels. Section 3 briefly overviews the data, methodology, and income concepts used in the analysis. Section 4 presents results for the two countries and discusses them in comparison. Section 5 concludes. 


\section{INEQUALITY, SOCIAL SPENDING, AND TAXATION IN BRAZIL AND THE US}

The Gini coefficient for equivalized disposable income was 0.376 in the US and 0.509 in Brazil in 2011. ${ }^{4}$ Both countries have been persistently unequal given their levels of development: a quarter century ago, Brazil had one of the highest levels of inequality in the world, while the US had one of the highest levels of inequality among developed countries. In 1989, Brazil's Gini coefficient made it the second most unequal country in the world, second only to Sierra Leone (Ferreira et al., 2008); in 1985, the United States was the second most unequal OECD country, second only to Turkey (OECD, 2011a). In 2010, Brazil was still among the twenty most unequal countries in the world (Alvaredo and Gasparini, forthcoming) and the US was the third most unequal OECD country behind Chile and Mexico. ${ }^{6}$ Furthermore, when the US was at a similar level of development as Brazil is today, it had similar levels of inequality: Plotnick et al. (1998) estimate that the Gini coefficient of monetary gross income in the United States in 1940 was around 0.55, similar to the level observed in Brazil today.

Inequality of opportunity in Brazil is among the highest of a large sample of countries, and is also relatively high in the United States compared to other developed countries, according to Brunori et al.'s (2013) meta analysis of inequality of opportunity studies that follow the measurement methods developed by Bourguignon et al. (2007) and Ferreira and Gignoux (2011). ${ }^{8}$ Both countries also exhibit low intergenerational mobility, with the lower mobility occurring in Brazil (Corak, 2011). In both countries, race plays an important role: in Brazil, it is an important determinant of inequality of opportunities (Roemer, forthcoming), while differences in the quality of schools attended by whites and blacks explains a substantial proportion of racial earnings gaps in the US (Card and Krueger, 1992).

Recently, inequality has fallen substantially in Brazil (Lustig et al., 2013b) while it has risen substantially in the United States (Kenworthy and Smeeding, forthcoming). If trends continue-and there is good reason to believe that they may ${ }^{9}$ - the level of inequality in the two countries could converge. Figure 1 shows the potentially converging levels of inequality in the two countries. ${ }^{10}$ Intergenerational mobility, which is closely related to equality of opportunity (Paes de Barros et al., 2009) and negatively correlated with overall inequality (Corak, 2013), is increasing in the very immobile Brazil (Ferreira et al., 2013) and decreasing in the somewhat more mobile US (Aaronson

\footnotetext{
${ }^{4}$ Equivalized disposable income refers to income after direct taxes and direct cash and food transfers, equivalized using the square root scale. These Gini coefficients are authors' calculations using the 2011 Current Population Survey for the US and the 2011 Pesquisa Nacional por Amostra de Domicílios for Brazil.

${ }^{5}$ This refers to countries that were members of the OECD in 1985.

${ }^{6}$ The finding that income inequality in the US is higher than in other developed countries is not an artifact of using "snapshot" cross-section data to measure inequality: when the time horizon is extended to several years, income inequality in the United States is still higher than in other advanced countries (Aaberge et al., 2002).

${ }^{7}$ In 1940, GDP per capita in the United States was around \$9,500 in 2009 dollars using GDP estimates from Bureau of Economic Analysis (2013) and population estimates from U.S. Census Bureau (2000); in Brazil, it was \$11,720 (in 2005 dollars adjusted for purchasing power parity) in the most recent year for which data is available, 2012 (World Bank, 2013).
} 
and Mazumder, 2008). Moreover, growth rates of incomes at the median and below are stagnant or falling in the United States, but rising in Brazil (Ferreira et al., 2010, Kenworthy, 2013).

\section{FIGURE 1. INEQUALITY IN THE US AND BRAZIL, 1990-2011}

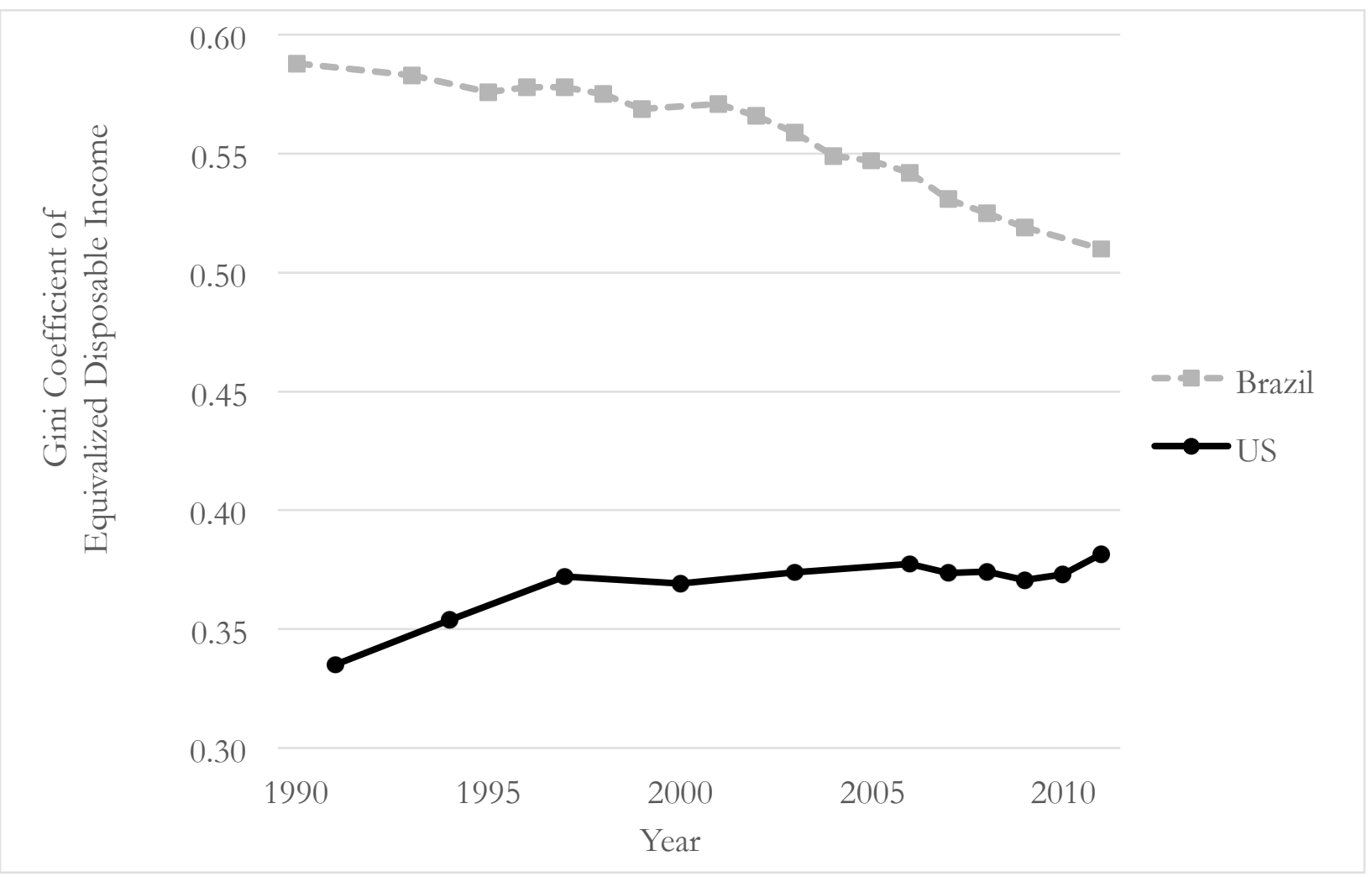

Notes: For the years for which US Gini coefficients are available from both LIS (2013) and Thompson and Smeeding (2013), they are very similar in the two sources. Ginis in the two countries are not perfectly comparable due to survey differences, slight differences in the definition of disposable income, and differences in the equivalence scale used in the two sources. On the latter, LIS (2013) and Thompson and Smeeding (2013) use the square root scale, while CEDLAS and the World Bank (2013) use an economies of scale parameter of 0.9 and also adjust for adult equivalence, weighting children ages 0 to 5 at 0.5 and children

${ }^{8}$ For detailed analyses of inequality of opportunity in the two countries, see Pistolesi (2009) for the US and Bourguignon et al. (2007) for Brazil.

${ }^{9}$ The factors contributing to increasing inequality in the United States show no signs of changing course (Kenworthy and Smeeding, forthcoming). Although it is less clear whether income inequality in Brazil will continue to decline (Lustig et al., 2013b), there are reasons to believe that it is very possible. Paes de Barros et al. (2010) argue that the factors contributing to the decline in inequality between 1977 and 2007 were beginning to experience decreasing marginal effectiveness. However, they note that the design of Brazilian social policy was far from optimal, and that there were therefore a number of avenues by which Brazil could maintain its recent fast pace of inequality decline without additional resources. Indeed, the Brazilian government has implemented at least one of Paes de Barros et al.'s (2010) suggestions by expanding the Bolsa Família conditional cash transfer program, and more recent data from 2008-2011 shows that inequality in Brazil has continued to decline.

${ }^{10}$ Also see Atkinson and Morelli (2012) which contains a longer time series of Gini estimates in Brazil and the US. 
ages 6 to 14 at 0.75 . Nevertheless, the Gini estimates from CEDLAS and the World Bank (2013) using this scale are similar to our own estimates from Brazil for 2001-2011 using the square root scale.

Sources: CEDLAS and the World Bank (2013) for Brazil; LIS (2013) for the US before 2000, Thompson and Smeeding (2013) for the US from 2000-2011.

Brazil's primary spending (total government spending at the federal, state, and local levels minus interest payments) was equal to 41.4 percent of GDP in 2009 (Ministério da Fazenda, 2010a), while that of the US was 38.6 percent of GDP in 2011 (International Monetary Fund, 2013, table 4a). Brazil spends more as a percent of GDP on direct transfers than the US (4.2 percent in Brazil compared to 3.3 percent in the US when pensions are not considered a transfer; the difference is even larger if pensions are considered a transfer, with spending of 13.2 percent of GDP in Brazil and 8.1 percent in the US). The countries spend approximately the same on non-tertiary education (4.1 percent of GDP in Brazil vs. 4.2 percent in the US). Despite Brazil providing free universal healthcare and the US merely subsidizing healthcare for the poor and elderly, the Brazilian government spends less on health (5.2 percent of GDP in Brazil vs. 6.3 percent in the US), reflecting the astronomically high healthcare costs in the US.

The composition of tax revenues differs substantially in the two countries, with the US relying heavily on direct taxes and Brazil relying heavily on expenditure taxes. In the US, the direct taxes included in our analysis (individual income, corporate income, and property taxes) account for 11.7 percent of GDP and the indirect taxes included (sales and excise taxes on consumption) represent 3.6 percent of GDP. Brazil collects less in these direct taxes than the US (8.2 percent of GDP) and much more from expenditure taxes (12.9 percent of GDP). When contributions to social security pensions are counted as a tax, the total taxes and contributions included in our analysis make up $21.4 \%$ of GDP in the US in 2011 and $28.2 \%$ of GDP in Brazil in 2009. ${ }^{11}$

\section{DATA, METHODOLOGY, AND INCOME CONCEPTS}

Using the methodological framework proposed in Lustig and Higgins (2013) to ensure maximum comparability across countries in concept and estimate, we perform comprehensive fiscal incidence analyses to measure the effect of taxation and social spending on inequality in the two countries. Our analysis includes direct taxes, direct transfers through cash and food programs, indirect expenditure taxes, indirect subsidies for energy and housing, and spending on government-provided health and education, valued at government cost. ${ }^{12}$ Because not all of the information was available

\footnotetext{
11 These numbers are for the taxes and contributions included in our analysis; when all taxes and contributionsincluding those not captured by our analysis - are taken into account, total taxes and contributions are 25.2\% of GDP in the US (International Monetary Fund, 2013, table 4a) and 34.4\% of GDP in Brazil (Ministério da Fazenda, 2010b). More information on the sources of the spending and revenue collection totals can be found in the notes to Table 2 . All numbers are for 2009 for Brazil and 2011 for the US to reflect the same years as our analysis.

12 This method equates expenditures with benefits, which is not necessarily true. For example, the method does not take into consideration the differences in quality of the services across income groups.
} 
in a single survey, we use several household survey data sets in our analysis. In the US, we use the Current Population Survey (2011) as our main survey and also use the American Community Survey (2011), National Household Survey (2011), and National Household Education Survey (2007); in Brazil, we use the Pesquisa de Orçamentos Familiares (2008-2009) as our main survey and also use the Pesquisa Nacional por Amostra de Domícilios (2008).

For our incidence analysis, we use definitions of five income concepts adapted from Lustig and Higgins (2013). Market income includes wage and salary income, fringe benefits (including employer contributions to health insurance), non-farm business income, farm income, retirement income, income from interest, dividends, and rent, income from private transfers (child support, alimony, remittances, other), imputed rent for owner-occupied housing, the value of own production, andin some parts of the analysis-income from contributory pensions from the social security system. Since gross labor income reported in the survey is net of taxes paid by the employer assuming these taxes are fully shifted forward resulting in lower wages, we gross up market income by adding taxes paid by the employer. Similarly, we gross up market income in the case of corporate income taxes. ${ }^{13}$

With respect to contributory social security pensions, Lustig et al. (forthcoming) explain that arguments exist for treating them as part of market income because they are deferred income similar to personal savings, as well as for treating them as a government transfer since there may not a deterministic link between the amount contributed and the benefit received, and many systems run a deficit financed by general tax revenues. Hence, for a number of tables we present results under both scenarios: the scenario in which they are treated as part of market income (the "benchmark case") and the one in which they are treated as a government transfer (the "sensitivity analysis"). In the benchmark case, we do not subtract contributions to social security out of income when moving from gross to disposable income because they are treated like any other form of personal savings. In the sensitivity analysis we do subtract out contributions, treating them as a tax. The results and comparison are sensitive to how contributory pensions are treated, which is unsurprising given Bourguignon et al.'s (2008) finding that a large portion of the difference in inequality in the two countries is due to the distribution of pensions.

Gross income equals market income plus direct cash and food transfers. In the case of Brazil, direct cash transfers include the flagship anti-poverty conditional cash transfer (CCT) program Bolsa Família, the non-contributory pension program Benefício de Prestação Continuada (BPC), public scholarships, unemployment benefits, special circumstances pensions, and other direct transfers (including benefits from state and municipal level programs, such as São Paolo state's Renda Cidadã CCT). Food transfers in Brazil include the Programa de Aquisição de Alimentos (PAA) milk transfer program. These programs are described in detail in Higgins and Pereira (forthcoming).

In the case of the US, direct cash transfers include welfare and welfare-to-work payments at the federal and state level, Temporary Assistance for Needy Families (TANF), Aid for Families with

\footnotetext{
${ }^{13}$ For more detail on grossing up, see for example Alm et al. (1990) and Wallace et al. (1991).
} 
Dependent Children (AFDC), non-contributory pensions from the Supplemental Security Income program, veterans' benefits, unemployment benefits, Pell grants (a type of scholarship funded by the federal government), and worker's compensation. We also treat refundable tax credits- the federal and state Earned Income Tax Credit (EITC), federal Child Tax Credit (CTC), and federal Making Work Pay (MWP) — as direct transfers (and, hence, use pre-credit liabilities in the direct tax calculations). ${ }^{14}$ Near-cash and food transfer programs in the US include the Supplemental Nutrition Assistance Program (SNAP; more commonly known as "food stamps"), Special Supplemental Nutrition Program for Women, Infants, and Children (WIC), and free and reduced-price school lunches for low-income families.

Disposable income equals gross income minus individual income taxes and payroll taxes (including those paid by the employer), corporate income taxes, and property taxes. Taxes at the federal, state, and local levels are included. Individual income taxes and payroll taxes are assumed to be borne fully by labor in the formal sector. Corporate income taxes are assumed to fall partially on capital, and to be partially shifted forward to labor and consumers. Due to the theoretical and empirical uncertainty with respect to who bears the burden of the corporate income tax (Auerbach, 2006), this is a middle of the road approach.

Property taxes are assumed to be borne fully by property owners. In Brazil, property taxes paid are directly identified in the expenditure module of the survey. In the US, they are not available in the survey; we use microsimulation-based estimates of property taxes paid by each quintile in each state from a secondary source to take into account the fact that different states have very different property tax rates and rely on very different tax mixes between property, personal income, corporate income, and sales taxes (Newman and O’Brien, 2011).

Post-fiscal income equals disposable income plus indirect subsidies minus indirect taxes. The indirect subsidies included in our analysis are housing and household energy subsidies targeted to lowincome families. Allocating other government subsidies to individual households proved to be intractable. In Brazil, the main housing subsidy program Minha Casa Minha Vida was not implemented until late 2009, after the survey was completed; hence, we do not include it in our analysis. In the US, a variety of targeted housing subsidies exist, which are all included in the analysis because the CPS question on housing assistance is ambiguous enough to include all programs; the benefit is imputed by estimating the market value rent of the dwelling and subtracting the reported rent paid, which is asked of those who receive housing subsidies. Energy subsidies come from Tarifa Social de Energia Elétrica (TSEE) in Brazil and Low-Income Home Energy Assistance (LIHEAP) in the US.

Indirect taxes are expenditure taxes at both the federal and state levels; in Brazil these include the main value-added taxes at the federal and state levels, while in the US they include federal and state sales and excise taxes. We assume that the burden of indirect taxes is entirely shifted forward to

${ }^{14}$ This is the same approach as that taken by the OECD (Denk et al., 2013). 
consumers. In the case of Brazil, we estimate expenditure taxes paid by each household using the expenditure module of POF in combination with effective tax rates for nine categories of consumption items calculated by Nogueira et al. (2011) using an input-output matrix. In the US, the CPS lacks consumption data, so we again use microsimulation-based estimates of sales taxes paid by each quintile in each state from a secondary source, which again accounts for the fact that different states have vastly different sales tax rates and tax mixes (Newman and O’Brien, 2011).

Final income equals post-fiscal income plus government spending on public education and health services. We value these services at government cost because our objective is to analyze who receives the benefits of public spending. In Brazil, unlimited free access to public health care facilities is guaranteed by the 1988 Constitution; within each state, we estimate the average cost of each of three types of care (basic, inpatient, and preventative) and assign this value to individuals who attended a public health facility in that state and received a treatment that falls under that type of care. In the United States, social spending on health care takes the form of the Medicare and Medicaid programs, which are imputed at their government cost to those who are covered by these public programs.

Education benefits are allocated to individuals who report attending a public daycare, pre-school, primary, or secondary school, and are valued at the per-pupil government spending for that education level. Public daycare programs for low-income families (either in the form of free daycare centers or subsidy vouchers) exist in both countries; in the US they are funded by the Child Care Development Fund (CCDF) and TANF. Public pre-school is available to all families in Brazil and to low-income families in the US, where it usually takes the form of participation in the Head Start program. Although tertiary education is free at all public universities in Brazil and highly subsidized at public universities in the US, the lack of data on who attends public universities in the US and the difficulty in allocating benefits led us to omit tertiary spending from our analysis for both countries. ${ }^{15}$

Each of these income concepts is aggregated at the household level and assumed to be shared equally among the members of the household (relative to their needs). If we assume no economies of scale within households, we would then divide household income by the number of people in the household and use household per capita income in the analysis. If we assume maximum economies of scale, so that the marginal cost of fulfilling the needs of any household member after the first is zero, then we would simply use household aggregate income in the analysis. Equivalence scales account for some degree of economies of scale within households between these two extremes. Often, these scales vary across nations' poverty and inequality estimates, and sometimes the assumptions made can take extreme forms (for instance, the World Bank generally uses household per capita incomes when estimating poverty, thereby assuming zero economies of scale within households). There is no one scale that is commonly used in the US and Brazil, but there is one simple scale employed in most cross-national comparisons of income inequality (Johnson and

\footnotetext{
${ }^{15}$ For an attempt to make such an estimate in Europe, see Callan et al. (2008). Higgins and Pereira (forthcoming) include tertiary spending in Brazil.
} 
Smeeding, forthcoming): the square root scale. This scale is a special case of the equivalence scales proposed by Buhmann et al. (1988), and was suggested by Atkinson et al. (1995). We apply this scale to both cash incomes (including cash benefits) and to public spending in education and health. ${ }^{16}$ Appendix A in the online supplement explores the robustness of our results to the choice of equivalence scale and presents results using household per capita income.

More detail about our assumptions and the allocation methods we use to allocate tax and transfer programs that could not be directly identified in the survey is provided in Appendix B in the online supplement.

\section{RESULTS}

Tables 1 and 2 show the effects on inequality of taxation and social spending by country, as well as the progressivity of various components of the tax and spending systems. Combined, they provide the broad elements we need to compare redistribution through fiscal policy in the US and Brazil.

TABLE 1. INCOME INEQUALITY BY INCOME CONCEPT IN THE UNITED STATES (2011) AND BRAZIL (2009)

\begin{tabular}{|c|c|c|c|c|c|}
\hline & $\begin{array}{l}\text { Market } \\
\text { Income }\end{array}$ & $\begin{array}{l}\text { Gross } \\
\text { Income }\end{array}$ & $\begin{array}{l}\text { Disposable } \\
\text { Income }^{c}\end{array}$ & $\begin{array}{l}\text { Post-Fiscal } \\
\text { Income }\end{array}$ & $\begin{array}{l}\text { Final } \\
\text { Income }\end{array}$ \\
\hline \multicolumn{6}{|c|}{ Benchmark case (pensions as market income) } \\
\hline \multicolumn{6}{|c|}{ United States } \\
\hline Gini $^{\mathrm{a}}$ & 0.448 & 0.417 & 0.376 & 0.378 & 0.331 \\
\hline Reduction $^{\mathrm{b}}$ & -- & -0.030 & -0.071 & -0.069 & -0.116 \\
\hline \multicolumn{6}{|l|}{ Brazil } \\
\hline Gini $^{a}$ & 0.551 & 0.532 & 0.512 & 0.509 & 0.432 \\
\hline Reduction $^{\mathrm{b}}$ & -- & -0.019 & -0.039 & -0.042 & -0.119 \\
\hline \multicolumn{6}{|c|}{ Sensitivity analysis (pensions as transfer) } \\
\hline \multicolumn{6}{|l|}{ United States } \\
\hline Gini $^{\mathrm{a}}$ & 0.484 & 0.416 & 0.372 & 0.374 & 0.325 \\
\hline Reduction $^{\mathrm{b}}$ & -- & -0.067 & -0.112 & -0.110 & -0.158 \\
\hline \multicolumn{6}{|l|}{ Brazil } \\
\hline Gini $^{\mathrm{a}}$ & 0.570 & 0.532 & 0.512 & 0.509 & 0.431 \\
\hline Reduction $^{\mathrm{b}}$ & -- & -0.039 & -0.058 & -0.061 & -0.139 \\
\hline
\end{tabular}

${ }^{16}$ For a discussion of the merits of this approach and its alternative (applying the equivalence scale to cash income but not to public spending in education and health) see Garfinkel et al. (2006). 
Notes: (a) Although results are only shown for the Gini coefficient, the same trends are observed using other inequality indicators such as the Theil index and 90/10 ratio, which are available from the authors on request. (b) Reduction is always in absolute terms and is with respect to market income. (c) Our disposable income Gini for the US in 2011 is similar to the disposable income Gini calculated for the US by Luxembourg Income Study (LIS) for 2010, which is 0.373 .

Sources: Authors' caluclations using Current Population Survey, American Community Survey, American Housing Survey, National Household Education Survey, Pesquisa de Orçamentos Familiares, and Pesquisa Nacional por Amostra de Domicílio.

TABLE 2. KAKWANI INDICES AND BUDGET SIZES FOR DIFFERENT TAX AND TRANSFER CATEGORIES

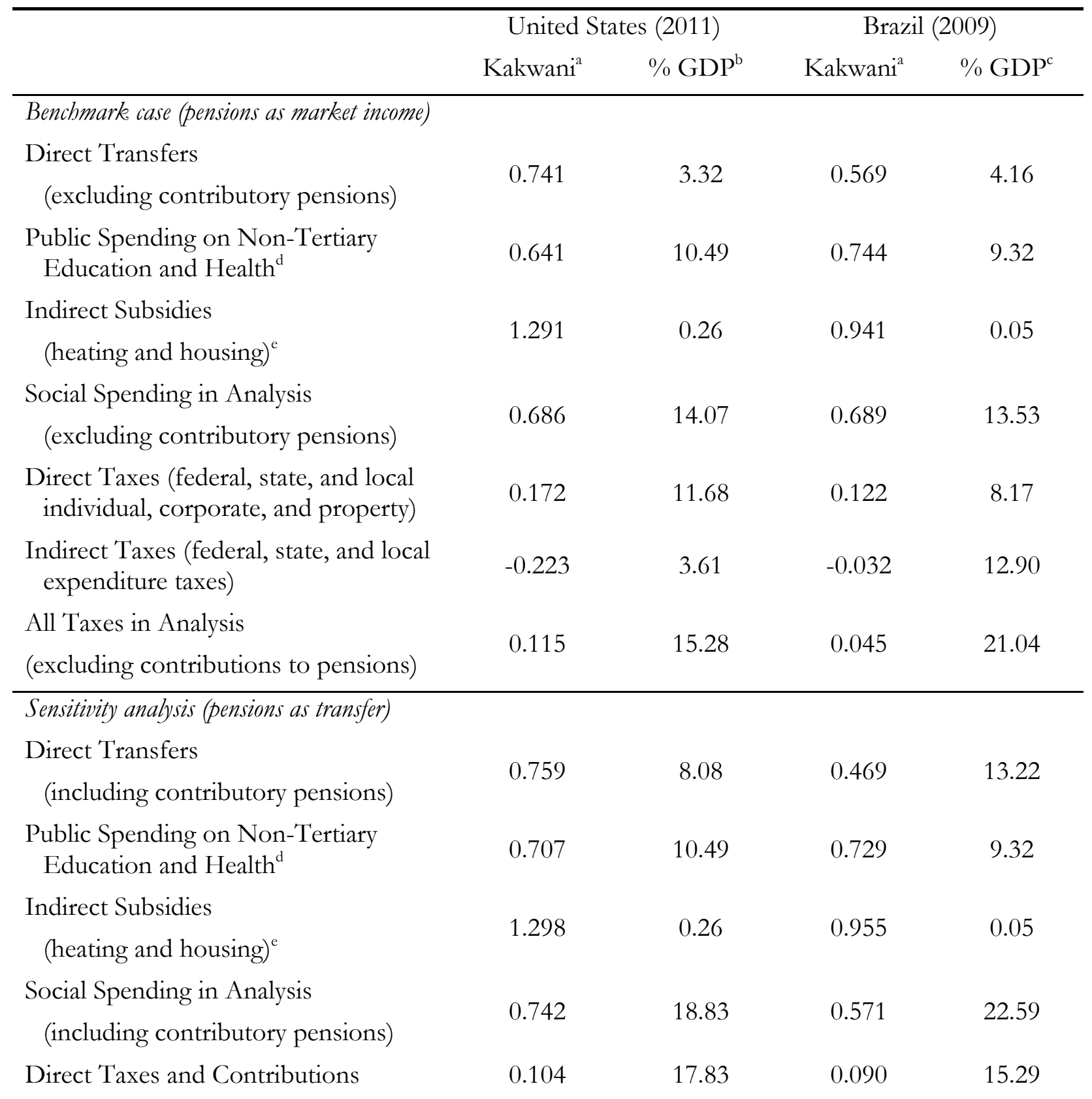


(federal, state, and local)

Indirect Taxes (federal, state, and local expenditure taxes)

$-0.244$

0.064
3.61

21.44
$-0.081$

0.011
12.90

28.16 Analysis

Notes: (a) The Kakwani coefficient is defined for taxes as the tax's concentration coefficient minus the market income Gini. For transfers it is defined as the market income Gini minus the transfer's concentration coefficient, so that a positive Kakwani always indicates progressivity. In the benchmark case, Kakwani coefficients are calculated with respect to benchmark case market income (which includes contributory pensions). In the sensitivity analysis, Kakwani coefficients are calculated with respect to sensitivity analysis market income (which does not include contributory pensions because they are treated as a government transfer). (b)-(c) Spending totals as a percent of GDP only include those taxes and transfers that are included in the analysis. (d) Non-tertiary education is the sum of public day care, preschool, primary, and secondary education spending. In Brazil, administrative education costs are listed as a separate line item, so we allocate them proportionally to each category of education spending. (e) Brazil's subsidized housing program Minha Casa Minha Vida was not included because it was implemented in late 2009, after the household survey was completed.

Sources: (a) Authors' calculations using Current Population Survey, American Community Survey, American Housing Survey, National Household Education Survey, Pesquisa de Orçamentos Familiares, and Pesquisa Nacional por Amostra de Domicílio. (b) Department of Health and Human Services' Administration for Children and Families, Department of Commerce's Bureau of Economic Analysis and Census Bureau, Department of Agriculture's Food and Nutrition Service, Department of Education budget overview, and Department of the Treasury's Internal Revenue Service. More detail on the source of each spending number is available in the online supplement. (c) Controladora Geral da União, Ministério da Agricultura Pecuária e Abastecimento, Ministério do Desenvolvimento Social e Combate à Fome, Ministério da Previdência e Assistência Social, Ministério do Trabalho, Secretaria de Avaliação e Gestão da Informação, Secretaria do Desenvolvimento Social do Governo do Estado de São Paulo, Secretaria do Tesouro Nacional.

\section{i Direct Cash and Food Transfers}

If we consider the impact of just direct transfers, the US reduces the Gini coefficient from 0.448 to 0.417, or by three percentage points (Table 1). To put this into international perspective among developed countries, the direct transfer system in the US is less redistributive than that of all EU countries. ${ }^{17}$ The six European countries with the largest redistribution through direct transfers (Ireland, the UK, Finland, Denmark, Sweden, and France) reduce their Gini coefficients by between eight and twelve percentage points due to direct transfers when one considers contributory pensions as part of market income (Immervoll et al., 2009). If we consider pensions as a transfer, the US is still less redistributive than any European country; this result is robust to comparisons with EU results from other studies (e.g., Goñi et al., 2011).

Brazil has a much higher market income Gini than the US of 0.551, and reduces inequality by even less than the US with direct transfers, to a gross income Gini of 0.532 , or by 1.9 percentage points.

\footnotetext{
17 The comparison with the EU countries uses numbers from Immervoll et al. (2009) which also broadly follows the same methodology (specifically, we calculate the reduction between the "private income plus pensions"—which we call market income-Gini and the gross income Gini in their Table 8.9).
} 
Why does Brazil achieve so much less redistribution than the United States through direct cash and food transfers, despite spending a larger share of GDP on direct transfers? Even when including the relatively large refundable tax credits and food assistance programs such as the Supplemental Nutrition Assistance Program (SNAP) in the total for direct transfers, the US spends 3.3 percent of GDP on direct transfers, compared to 4.2 percent in Brazil. This difference is even more pronounced if contributory pensions are considered a government transfer, in which case the US spends 8.1 percent of GDP compared to 13.2 percent in Brazil. However, transfer spending is much more progressive in the US: the Kakwani index ${ }^{18}$ for direct transfers in the US is 0.741 (0.759) while in Brazil it equals 0.569 (0.469) when pensions are not (are) counted as a government transfer (Table 2).

Furthermore, every direct income transfer program in the US except Social Security pensions (if the latter are considered a government transfer) is progressive in absolute terms-i.e., the per capita transfer decreases with income. In contrast, in Brazil the larger direct transfer programs are progressive only in relative terms - that is, benefits as a proportion of income, but not per capita benefits, decrease with income. This can be seen in Tables 3 and 4, where the concentration coefficients for all direct transfer programs in the US except contributory pensions are negative, while they are positive (but less than the market income Gini, indicating that they are still equalizing) for some programs in Brazil.

TABLE 3. CONCENTRATION COEFFICIENTS OF TRANSFERS PROGRAMS AND THEIR SIZE, UNITED STATES 2011

\begin{tabular}{|c|c|c|c|c|}
\hline \multirow[b]{2}{*}{ Program } & \multicolumn{2}{|c|}{ Concentration coefficient } & \multicolumn{2}{|c|}{ Program size } \\
\hline & $\begin{array}{l}\text { w.r.t. benchmark } \\
\text { case market } \\
\text { income }\end{array}$ & $\begin{array}{l}\text { w.r.t. sensitivity } \\
\text { analysis market } \\
\text { income }\end{array}$ & $\begin{array}{l}\text { in billions } \\
\text { of US } \\
\text { dollars }\end{array}$ & $\begin{array}{l}\text { as a percent } \\
\text { of GDP }\end{array}$ \\
\hline $\begin{array}{l}\text { Total Social Spending including } \\
\text { Pensions }^{\mathrm{a}}\end{array}$ & -0.165 & -0.259 & 2822.9 & 18.83 \\
\hline $\begin{array}{l}\text { Total Social Spending excluding } \\
\text { Pensions }\end{array}$ & -0.238 & -0.245 & 2109.6 & 14.07 \\
\hline Direct Transfers including & -0.126 & -0.276 & 1210.9 & 8.08 \\
\hline \multicolumn{5}{|c|}{$\begin{array}{l}{ }^{18} \text { Note that the index originally proposed by Kakwani (1977) only measures the progressivity of taxes. It is defined as } \\
\text { the tax's concentration coefficient minus the market income Gini. To adapt to the measurement of transfers, Lambert } \\
\text { (1985) suggests that in the case of transfers it should be defined as market income Gini minus the concentration } \\
\text { coefficient (i.e., the negative of the definition for taxes) to make the index positive whenever the change is progressive. } \\
\text { Also note that in the case of transfers, the Kakwani index can exceed unity (Lambert, 2001). Hence, a negative Kakwani } \\
\text { indicates a regressive tax or transfer, while a positive Kakwani indicates a progressive tax or transfer; the index is higher } \\
\text { the more progressive the tax or transfer. In the case of transfers, a Kakwani that is both positive and higher than the } \\
\text { market income Gini indicates that the transfer is progressive in absolute terms-in other words, the absolute benefit } \\
\text { decreases with income- while a Kakwani that is positive and less than the market income Gini indicates that the transfer } \\
\text { is progressive in only relative terms - that is, the benefit as a proportion of income (but not the absolute benefit) } \\
\text { decreases with income. }\end{array}$} \\
\hline
\end{tabular}




\begin{tabular}{|c|c|c|c|c|}
\hline \multicolumn{5}{|l|}{ Pensions $^{\mathrm{b}}$} \\
\hline Total Health Spending ${ }^{c}$ & -0.270 & -0.402 & 949.0 & 6.33 \\
\hline Contributory Pensions (SS) & 0.005 & -0.290 & 713.3 & 4.76 \\
\hline $\begin{array}{l}\text { Total Non-Tertiary Education } \\
\text { Spending }^{\mathrm{d}}\end{array}$ & -0.131 & -0.077 & 623.9 & 4.16 \\
\hline $\begin{array}{l}\text { Primary and Secondary } \\
\text { Education }\end{array}$ & -0.122 & -0.068 & 602.6 & 4.02 \\
\hline Medicare & -0.118 & -0.333 & 545.1 & 3.64 \\
\hline $\begin{array}{l}\text { Direct Transfers excluding } \\
\text { Pensions }^{\text {e }}\end{array}$ & -0.293 & -0.258 & 497.6 & 3.32 \\
\hline Medicaid & -0.525 & -0.518 & 403.9 & 2.69 \\
\hline Unemployment Benefits & -0.214 & -0.177 & 108.0 & 0.72 \\
\hline SNAP (food stamps) & -0.719 & -0.664 & 72.7 & 0.49 \\
\hline Veteran's Benefits & -0.088 & -0.217 & 63.6 & 0.42 \\
\hline Federal EITC & -0.565 & -0.471 & 62.9 & 0.42 \\
\hline $\begin{array}{l}\text { SSI for aged, blind, disabled } \\
\text { (non-contributory pension) }\end{array}$ & -0.623 & -0.607 & 50.4 & 0.34 \\
\hline Pell Grants & -0.200 & -0.148 & 34.8 & 0.23 \\
\hline Housing Subsidies & -0.854 & -0.823 & 34.2 & 0.23 \\
\hline State EITC & -0.622 & -0.549 & 24.8 & 0.17 \\
\hline Welfare, TANF, AFDC & -0.762 & -0.710 & 21.1 & 0.14 \\
\hline Worker's Compensation & -0.077 & -0.123 & 15.8 & 0.11 \\
\hline Public Childcare & -0.241 & -0.173 & 13.7 & 0.09 \\
\hline School Lunch & -0.505 & -0.432 & 10.1 & 0.07 \\
\hline Head Start & -0.706 & -0.632 & 7.6 & 0.05 \\
\hline WIC & -0.623 & -0.539 & 4.9 & 0.03 \\
\hline Energy Subsidies & -0.721 & -0.711 & 4.8 & 0.03 \\
\hline Federal CTC & -0.130 & -0.062 & 3.4 & 0.02 \\
\hline
\end{tabular}

Note: AFDC $=$ Aid to Families with Dependent Children. CTC $=$ Child Tax Credit. EITC $=$ Earned Income Tax Credit. GDP = Gross Domestic Product. SNAP = Supplemental Nutrition Assistance Program. SS = Social Security. SSI $=$ Supplemental Security Income. TANF $=$ Temporary Assistance for Needy Families. w.r.t. = with respect to. Programs are listed from largest to smallest. Market incomes and transfers are measured in equivalized terms using the square root scale. (a) Total social spending including (excluding) pensions is composed of direct transfers including (excluding) pensions, total health spending, total nontertiary education spending, energy subsidies, and housing subsidies. (b) Direct transfers including pensions is composed of direct transfers excluding pensions and contributory pensions (SS). (c) Total health spending is composed of Medicare and Medicaid. (d) Total non-tertiary education spending is composed of primary and secondary education, Head Start, and public childcare. Tertiary education is not included in our analysis. (e) Direct transfers excluding pensions is composed of welfare, TANF, AFDC, SSI, Pell grants, veterans' benefits, unemployment benefits, worker's compensation, SNAP, WIC, school lunch, federal EITC, federal CTC, state EITC, and the Making Work Pay refundable tax credit. 
Sources: Concentration coefficients are authors' calculations using Current Population Survey, American Community Survey, American Housing Survey, and National Household Education Survey. Program sizes are from the Department of Health and Human Services' Administration for Children and Families, Department of Commerce's Bureau of Economic Analysis and Census Bureau, Department of Agriculture's Food and Nutrition Service, and Department of Education budget overview.

TABLE 4. CONCENTRATION COEFFICIENTS OF TRANSFERS PROGRAMS AND THEIR SIZE, BRAZIL 2009

\begin{tabular}{|c|c|c|c|c|}
\hline \multirow[b]{2}{*}{ Program } & \multicolumn{2}{|c|}{ Concentration coefficient } & \multicolumn{2}{|c|}{ Program size } \\
\hline & $\begin{array}{l}\text { w.r.t. benchmark } \\
\text { case market } \\
\text { income }\end{array}$ & $\begin{array}{l}\text { w.r.t. sensitivity } \\
\text { analysis market } \\
\text { income }\end{array}$ & $\begin{array}{l}\text { in billions } \\
\text { of US } \\
\text { dollars }^{\mathrm{g}}\end{array}$ & $\begin{array}{l}\text { as a percent } \\
\text { of GDP }\end{array}$ \\
\hline $\begin{array}{l}\text { Total Social Spending including } \\
\text { Pensions }\end{array}$ & 0.162 & 0.016 & 420.4 & 22.59 \\
\hline $\begin{array}{l}\text { Total Social Spending excluding } \\
\text { Pensions }^{\mathrm{a}}\end{array}$ & -0.139 & -0.128 & 251.8 & 13.53 \\
\hline $\begin{array}{l}\text { Direct Transfers including } \\
\text { Pensions }{ }^{\mathrm{b}}\end{array}$ & 0.383 & 0.126 & 246.0 & 13.22 \\
\hline Contributory Pensions & 0.544 & 0.199 & 168.6 & 9.06 \\
\hline Total Health Spending & -0.125 & -0.109 & 97.0 & 5.21 \\
\hline $\begin{array}{l}\text { Direct Transfers excluding } \\
\text { Pensions }^{c}\end{array}$ & -0.018 & -0.059 & 77.3 & 4.16 \\
\hline $\begin{array}{l}\text { Total Non-Tertiary Education } \\
\text { Spending }^{\mathrm{d}}\end{array}$ & -0.272 & -0.216 & 76.4 & 4.11 \\
\hline Primary Education & -0.288 & -0.230 & 59.4 & 3.19 \\
\hline Special Circumstances Pensions ${ }^{\mathrm{e}}$ & 0.142 & 0.058 & 42.4 & 2.28 \\
\hline Unemployment & 0.154 & 0.212 & 10.9 & 0.58 \\
\hline $\begin{array}{l}\text { BPC (non-contributory } \\
\text { pensions) }\end{array}$ & -0.472 & -0.483 & 9.9 & 0.53 \\
\hline Secondary Education & -0.180 & -0.138 & 9.5 & 0.51 \\
\hline Public Childcare $^{\mathrm{f}}$ & -0.266 & -0.197 & 7.6 & 0.41 \\
\hline Preschool $^{\mathrm{f}}$ & -0.328 & -0.263 & & 0.00 \\
\hline Bolsa Família (CCT) & -0.561 & -0.498 & 7.3 & 0.39 \\
\hline Other Direct Transfers & 0.124 & 0.176 & 4.8 & 0.26 \\
\hline Scholarships & 0.274 & 0.309 & 2.1 & 0.11 \\
\hline Energy Subsidies & -0.390 & -0.385 & 1.0 & 0.05 \\
\hline Milk Transfers & -0.410 & -0.379 & 0.1 & 0.01 \\
\hline
\end{tabular}

Note: BPC = Benefício de Prestação Continuada. CCT $=$ Conditional Cash Transfer. GDP = Gross Domestic Product. Programs are listed from largest to smallest. Market incomes and transfers are measured 
in equivalized terms using the square root scale, which explains the differences between these concentration coefficients and those in Pereira and Higgins (forthcoming). (a) Total social spending including (excluding) pensions is composed of direct transfers including (excluding) pensions, total health spending, total nontertiary education spending, energy subsidies, and housing subsidies. Brazil's main housing subsidy program, Minha Casa Minha Vida, was not included in the analysis because it was implemented in late 2009 after the household survey was completed. (b) Direct transfers including pensions is composed of direct transfers excluding pensions and contributory pensions. (c) Direct transfers excluding pensions is composed of Bolsa Família, BPC, scholarships, unemployment benefits, special circumstances pensions, milk transfers, and other direct transfers. (d) Total non-tertiary education spending includes public daycare and pre-school, primary, and secondary education. Administrative costs are a separate line item in Brazil, so they are distributed proportionally to each education category (including tertiary which is not included in our analysis). (e) These are considered a non-contributory pension for reasons described in Higgins and Pereira (forthcoming). (f) The budgets for public childcare and preschool are combined in public accounts. (g) Conversion to US dollars uses the consumption-based purchasing power parity (PPP) adjusted exchange rate for 2009.

Sources: Concentration coefficients are authors' calculations using Pesquisa de Orçamentos Familiares and Pesquisa Nacional por Amostra de Domicílio. Program sizes are from Controladora Geral da União, Ministério da Agricultura Pecuária e Abastecimento, Ministério do Desenvolvimento Social e Combate à Fome, Ministério da Previdência e Assistência Social, Ministério do Trabalho, Secretaria de Avaliação e Gestão da Informação, Secretaria do Desenvolvimento Social do Governo do Estado de São Paulo, Secretaria do Tesouro Nacional. One reason Brazil is not able to achieve more redistribution through direct transfers is that its highly progressive programs — such as its flagship CCT Bolsa Família, noncontributory pension program for the elderly poor BPC, and milk transfer program-are small: combined, the three programs make up less than 1 percent of GDP. Even for the poorest 10 percent of the population, they only increase market income by 28.0 percent, 10.0 percent, and a paltry 0.2 percent, respectively. ${ }^{19}$ This can be compared to the United States where the Supplemental Security Income program for the aged, blind, and disabled increases the market incomes of the bottom decile by 28.8 percent on average, while (the monetized values of) food assistance transfers (SNAP, WIC, and the school lunch program) increase their incomes by 38.0 percent.

Meanwhile, the majority of Brazil's larger transfer programs, such as unemployment benefits, are progressive only in relative terms (Table 4) — that is, the ratio of transfer to income declines with income, but the absolute value of the transfer does not decline with income. The effect of these large and only relatively progressive programs on the redistributive impact of direct transfers can be seen in the concentration curve for direct transfers (the solid dark gray curve) in Figure 2: it begins concave and above the 45 degree line due to well-targeted programs like Bolsa Familia, but then becomes convex and crosses the 45 degree line due to the larger less progressive programs. In fact, if contributory pensions are considered a government transfer, total direct transfers are progressive in relative terms only (as seen by the fact that their concentration coefficient is positive but less than the market income Gini in Table 4): the better off benefit more in absolute terms from direct transfers than the poor.

\footnotetext{
19 Part of the reason that the non-contributory pension program only increases incomes of the poorest decile by 10 percent could be that recipients of the non-contributory pension program are not aware what program they received benefits from and hence do not report benefits from this program. Indeed, only $40 \%$ of the total number of beneficiaries according to administrative records were identified in the 2004 PNAD, which had a special supplement that asked three questions specifically about BPC (Soares et al., 2007).
} 
FIGURE 2. CONCENTRATION CURVES FOR TAX AND SPENDING CATEGORIES (BENCHMARK CASE), BRAZIL 2009

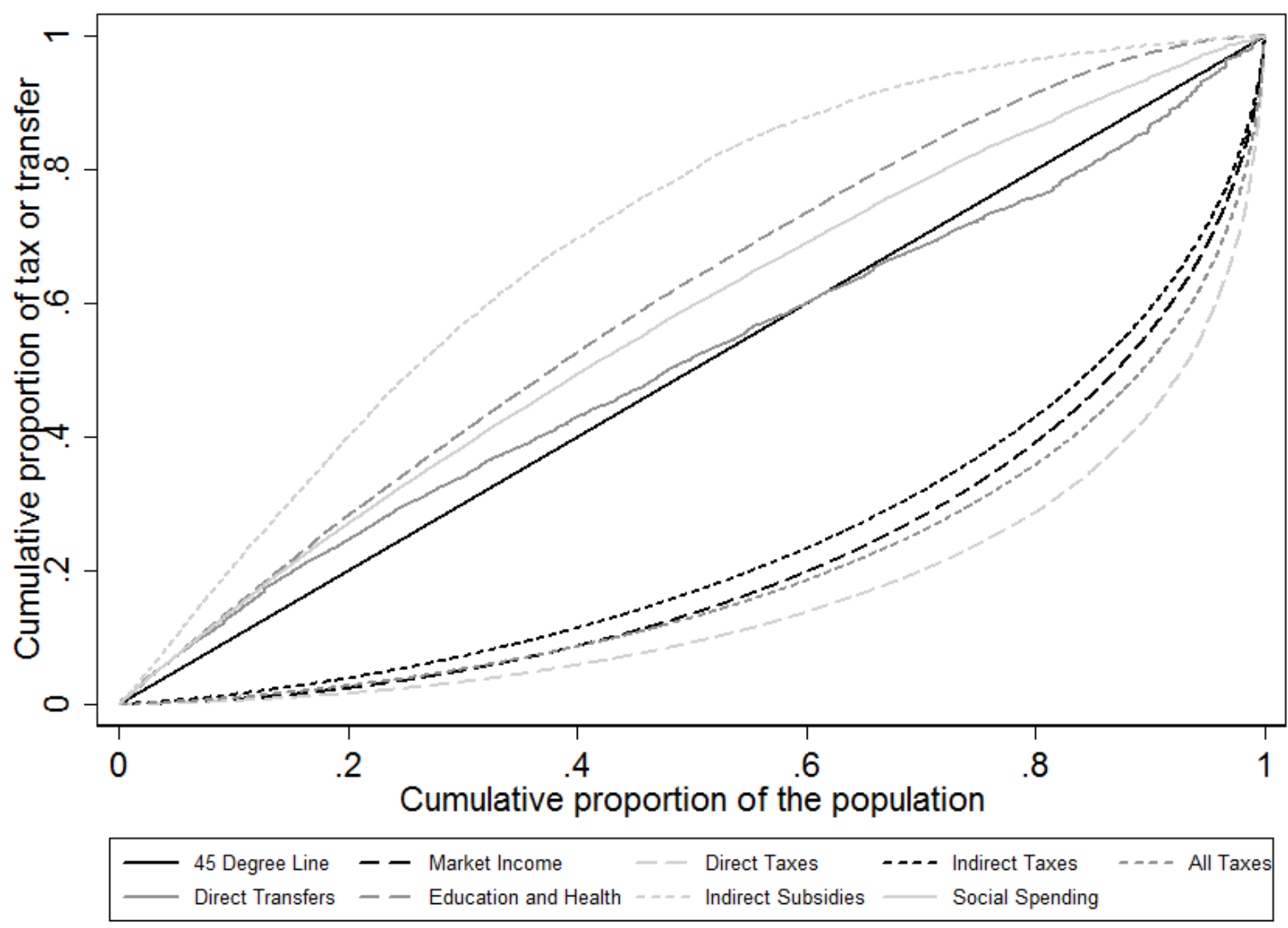

Source: Authors' elaboration using Pesquisa de Orçamentos Familiares and Pesquisa Nacional por Amostra de Domicilio.It is worth noting that the US was an economy in recovery in 2011, with an adult employment to population ratio still three percentage points below pre-recession levels (Kenworthy and Smeeding, forthcoming) and a budget deficit larger than before the recession (Congressional Budget Office, 2013). These circumstances likely increased the amount of redistribution observed, especially given the countercyclical nature of transfer programs such as food stamps (Ziliak, 2013).

\section{ii Direct Taxes}

Direct taxes reduce the Gini in the US by another four percentage points when moving from gross income to disposable income, compared to a two percentage point reduction in Brazil (Table 1). The discrepancy is slightly larger when pensions are treated as a government transfer (and hence contributions to the pension system are treated as a tax). Because the order that taxes and transfers are analyzed is somewhat arbitrary and the relative contribution of each to inequality reduction can be sensitive to the order chosen (Kim and Lambert, 2009), we also test the sensitivity of our comparisons of the redistributive effect of taxes and transfers in the two countries to adopting the opposite order and first subtracting taxes from market income to arrive at net market income. The net market income benchmark case Ginis for the US and Brazil are 0.415 and 0.533, respectively, 
meaning that under this alternate path, direct taxes reduce the Gini coefficient by 3.2 percentage points in the US and 1.7 percentage points in Brazil.

Throughout Latin America, the individual income tax is underutilized as a revenue collection and redistributive tool (Corbacho et al., 2013). Direct taxes in Brazil are both smaller and less progressive than in the US. In Brazil, revenues from individual income taxes (at the federal, state, and local levels) only amount to 2.1 percent of GDP, compared to 9.3 percent for individual income taxes (at the federal, state, and local levels) in the US. Total direct taxes analyzed in this study-including individual income, corporate income, and property taxes at the federal, state, and local levels-are 11.7 percent of GDP in the US and 8.2 percent in Brazil. Furthermore, direct taxes are much more progressive in the US: the Kakwani index (which measures the progressivity of a tax based on its concentration in the income distribution and is independent of the tax's size) is 0.172 in the US, compared to 0.122 in Brazil (Table 2).

High levels of informality in Brazil may limit its ability to increase revenue collection from the individual income tax, considering that around 50 percent of Brazilian workers are informal and Brazil already collects personal income taxes at levels comparable to other middle-income countries (Corbacho et al., 2013). While some assume that the income tax's existence per se encourages informality, the evidence on whether personal income taxes have increased informality in Latin America is mixed (Lora and Fajardo, 2012a); furthermore, the benefits of evasion are diminished in a general equilibrium framework (Alm and Sennoga, 2010), possibly to zero (Alm and Finlay, 2013). Two likely causes of Brazil's persistent informality are that labor productivity has not increased at the same pace as minimum wages and contribution requirements, and that the effective rate on capital is significantly lower than that on labor, which can discourage firms from creating laborintensive employment in the formal sector (Lora and Fajardo, 2012b).

Non-contributory pension programs and CCTs can also be double-edged swords by encouraging informality. Evidence exists that these programs have increased informality in Argentina (Garganta and Gasparini, 2012), Colombia (Camacho et al., 2013), and Mexico (Bosch and Campos, 2010). In Brazil, per-beneficiary non-contributory pension benefits are larger than in any other Latin American country; these large benefits could discourage formal employment by reducing the relative benefits of enrollment in the contributory pension system (Levy and Schady, 2013).

An additional factor working against Brazil is that the higher initial income inequality is — and it is much higher in Brazil than in the US - the more difficult it is to reduce income inequality through progressive taxes and transfers (Engel et al., 1999).

\section{iii Expenditure taxes}

Expenditure taxes are fairly regressive in the United States and slightly regressive in Brazil, with Kakwani coefficients of -0.252 and -0.032 , respectively. Poterba (1989) and Capeau et al. (forthcoming) argue that the progressivity of indirect taxes should be measured with respect to consumption rather than income. Although this changes the assessment of indirect taxes from regressive to progressive in many Latin American countries (Corbacho et al., 2013, table 9.3), this is 
not the case for Brazil: the Kakwani index for indirect taxes with respect to consumption is -0.098 , indicating that indirect taxes are regressive in Brazil even when their progressivity is calculated with respect to consumption. ${ }^{20}$ For the US, our CPS data does not include consumption, but given how regressive indirect taxes are with respect to income, it is safe to assume that they would still be regressive with respect to consumption.

Comparing the concentration curves for indirect taxes in the two countries helps one to appreciate the extent to which they are more regressive in the United States than Brazil (see the dotted black lines in Figures 2 and 3). However, they are larger in Brazil, making up more than half of total tax revenue at the federal, state, and local levels combined. This can also be seen in Figures 2 and 3: the dotted dark gray concentration curve for all taxes in Brazil is about halfway in between the dashed light gray progressive concentration curve for direct taxes and the dotted black regressive concentration curve for indirect taxes, while in the United States it is pulled largely by the progressive concentration curve for direct taxes since these make up a larger share of the tax mix.

FIGURE 3. CONCENTRATION CURVES FOR TAX AND SPENDING CATEGORIES (BENCHMARK CASE), US 2011

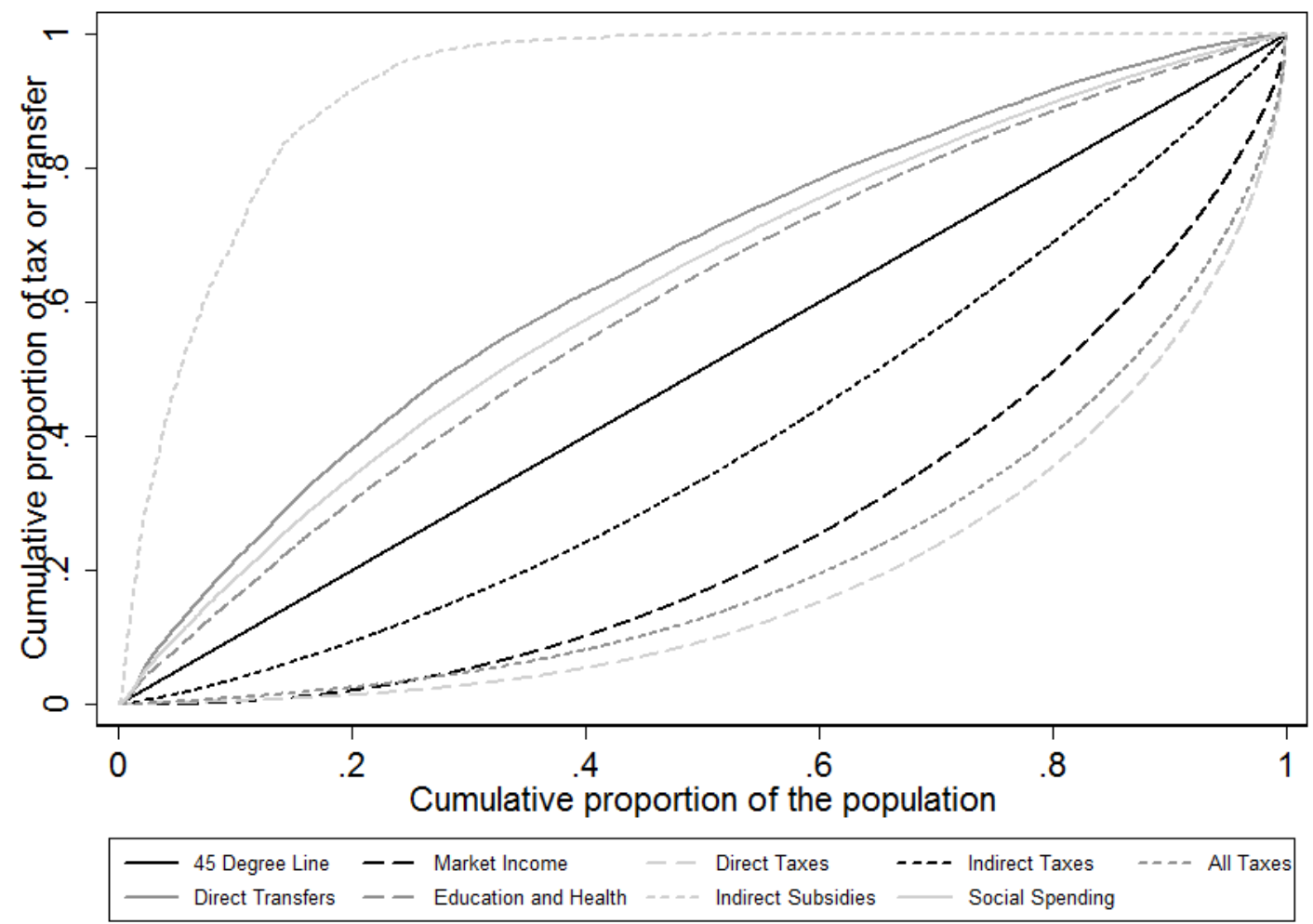

20 The Kakwani for indirect taxes with respect to consumption is the authors' calculation using POF. Brazil is not included in the aforementioned table of Corbacho et al. (2013). 
Source: Authors' calculations using Current Population Survey, American Community Survey, American Housing Survey, and National Household Education Survey.In both countries, the poor pay a significant portion of their (market) income in indirect taxes: ${ }^{21}$ the poorest decile in Brazil pays 22 percent of its market income in indirect taxes and that of the US pays 16 percent. In March 2013, Brazil announced that it would end federal (but not state) taxes on a number of basic food items, which will likely mitigate this large effect on the poor. In contrast, in the United States, many states have been moving in the opposite direction by increasing their regressive sales taxes and, in some cases, decreasing income and property taxes. ${ }^{22}$ These sales taxes place a large burden on the poor, and not only financially: Newman and O'Brien (2011) exploit intra-state variation over time in the tax burden on the poor (in the US) and find that a higher tax burden on the poor has a statistically and economically significant impact on mortality, obesity, and violent crime.

The high burden of indirect taxes on the poor in both countries can also be seen by the fact that, when all taxes are taken together (dotted dark gray curve in Figures 1 and 2), although the overall tax mix is summarized as progressive by the Kakwani index in both countries, it is not progressive across the entire distribution. The concentration curve for all taxes lies above the market income Lorenz curve at the lower end of the distribution-for at least the poorest 20 percent of the population in the US and the poorest 15 percent in Brazil-indicating that these individuals pay a larger proportion of total taxes than their proportion of income. We verify the statistical significance of this result by testing a null hypothesis of non-dominance on these restricted domains, using the asymptotic sampling distributions for Lorenz and concentration curves derived by Davidson and Duclos (1997).

\section{iv Indirect Subsidies}

Subsidies are highly progressive in both the US and Brazil, as can be seen by the dotted light gray curves in Figures 1 and 2. These programs, which are among the best-targeted in each country, include energy subsidies for households who consume below a certain quantity of kilowatt-hours per month (and, in some cases, also have income below a certain threshold) and subsidized housing for low-income families. In the US, housing subsidies are more progressive and well-targeted than any other program, with a concentration coefficient of -0.854 (Table 3) and 93 percent of benefits going to the poorest 20 percent (bottom quintile) of the population. Household energy subsidies are also very progressive in the US, with a concentration coefficient of -0.721 , making them the third most

\footnotetext{
${ }^{21}$ Not disposable income, which is significantly higher for the poorest decile. Hence, they pay a lower percent of their disposable income in indirect taxes.

22 Out of four sources of tax revenue-property tax, sales tax, individual income tax, and corporate income tax-the Midwest and West regions of the US have shifted from relying on property taxes more than any other tax in 1957 to relying on sales taxes more than any other in 2006 (Newman and O'Brien, 2011). Between 2007 and 2011, thirteen states and the District of Columbia increased state sales tax rates (Tax Foundation, 2012). A very recent example of a state that has simultaneously increased sales taxes and reduced income taxes is Ohio, whose tax reform went into effect on September 1, 2013. Globalization may provide additional pressure on states and the country as a whole to shift from individual and corporate income taxes to expenditure taxes (Hines and Summers, 2009).
} 
progressive program in the country behind heating subsidies and welfare benefits. 23 They are also well-targeted, with 74 percent of benefits going to the bottom quintile.

In Brazil, the main housing subsidy program Minha Casa Minha Vida was not implemented until late 2009 (after the household survey had already taken place), so it is not included in our analysis. Targeted energy subsidies constitute the fourth-most progressive program in Brazil, behind its welltargeted cash transfer programs (Bolsa Família and BPC) and its milk transfer program. The program is less well-targeted than in the US, with 40 percent of benefits going to the poorest quintile of the population. In addition, the program is extremely small, at 0.05 percent of GDP, which limits its redistributive impact.

\section{$\checkmark$ Public Spending on Non-Tertiary Education and Health}

As noted in Gafinkel et al. (2006), public spending on non-tertiary education and health is a particularly important part of redistribution in the US: when it is included in the analysis, the gap in terms of redistribution between the US and Europe is significantly reduced. In our analysis, this manifests itself in the fact that, when adding government spending on public childcare, the Head Start preschool program, primary and secondary education, and health spending on the poor and elderly through Medicaid and Medicare to incomes, the Gini is reduced by a further five percentage points, from a post-fiscal income Gini coefficient of 0.378 to a final income Gini of 0.331 in the benchmark case. This result must be treated with caution, however, since no adjustment is made for quality of service; the public spending allocated to households is inflated by the fact that healthcare costs in the US are astronomically high, but health outcomes are no better than in European countries where healthcare is significantly less expensive (Anderson et al., 2003). Keeping this caveat in mind, social spending and taxation as a whole in the United States (excluding contributory pensions) results in a twelve percentage point reduction in the Gini coefficient between market and final income, from 0.448 to 0.331 . When pensions are considered a transfer and contributions treated as a tax, social spending and taxation as a whole reduces income inequality by sixteen percentage points, from 0.484 to 0.325 .

All components of education spending (public childcare, Head Start, and primary and secondary) are progressive in absolute terms, meaning that the poor benefit more than proportionally to their population size. This result is not always desirable, however; the absolute progressivity of primary and secondary education, for example, may be the result of rich families choosing to send their children to private schools due to quality concerns. In contrast, the high absolute progressivity of the Head Start program (with a concentration coefficient of -0.706) is due to the deliberate targeting by the government of a program with limited budget resources. Under the current (and tightening) budget constraints of the program, the high level of progressivity indicates that it is reaching the neediest families, for whom returns to investment in early childhood education are highest

23 "Welfare" includes a number of programs including longstanding welfare programs, as well as newer programs such as AFDC and TANF. 
(Heckman, 2011) and whose children often otherwise reach kindergarten already possessing a large cognitive gap relative to their peers that persists throughout their education (Heckman, 2008).

In Brazil, health and non-tertiary education spending has an even larger impact on income distribution: when adding government spending on non-tertiary education and health to income, the Gini coefficient is reduced by nearly eight additional percentage points, from a post-fiscal income Gini of 0.509 to a final income Gini of 0.432 (Table 1). These results should again be treated with caution, since the high redistributive effect of spending on education and health may be caused by members of the middle and upper classes opting out of these services (and instead going to the private sector) due to quality concerns (Ferreira et al., 2013).

The conclusion that health and non-tertiary education spending had a larger redistributive impact in Brazil than the United States must also be treated with caution, since quality of services is not taken into account. Although both countries spend just over four percent of GDP on non-tertiary education, average Brazilian scores on the Program for International Student Assessment (PISA) test are almost two standard deviations lower than US scores. This is to be expected given the spending discrepancies between the two countries in absolute terms, but Brazil also scores poorly relative to its level of development, reflecting low-quality education. Brazil's composite PISA score places it just below Jordan, which had a PPP-adjusted GDP per capita of just 55 percent of Brazil's in 2009, and up to a standard deviation below some other middle-income countries such as Serbia and Turkey (OECD, 2010). ${ }^{24}$ Nevertheless, it is worth taking note of recent evidence that, on the margin, increased education spending does translate to better schooling outcomes in Brazil (Litschig and Morrison, 2013).

Without dismissing these caveats, social spending and taxation (excluding pensions) reduce the Gini coefficient by twelve percentage points in Brazil - the same amount as the Gini is reduced in the US. In contrast with the US, in Brazil the Gini reduction (from a market income Gini of 0.551 to a final income Gini of 0.432) was due mostly to public spending on education and health. When contributory pensions are treated as a government transfer and contributions as a tax, the Brazilian Gini is reduced from 0.570 to 0.431 , or by fourteen percentage points-slightly less than the sixteen percentage point reduction in the US.

Our analysis does not include tertiary education for comparability with the US, where data limitations prevented us from being able to identify the beneficiaries of public university spending. However, when the distribution of tertiary benefits are analyzed for Brazil, the results are abhorrent: tertiary education spending has a concentration coefficient of 0.472 . This is fairly close to the Gini coefficient for income, indicating that the rich benefit about proportionally to their income from

\footnotetext{
24 These results use 2009 PISA results reported in OECD (2010). In each of the three categories (reading, math, and science), average student scores are reported by country. We calculate composite score for the country by averaging across the average student score in these three subjects, giving equal weight to each subject, and calculate the standard deviation using each country's composite score as an observation. PPP-adjusted GDP per capita comparisons are based on World Bank (2013).
} 
tertiary education. Furthermore, Higgins and Pereira (forthcoming) find that, while 39 percent of the population aged $18-23$ is poor, ${ }^{25}$ only 9 percent of $18-23$ year olds who attend tertiary institutions belong to this group.

\section{CONCLUSIONS}

This paper presents the first direct comparison of fiscal incidence in Brazil and the United States, using household survey data and a combination of allocation techniques including direct identification, microsimulation, inference, and imputation. Such comparisons are indeed of interest because income inequality is high in both countries given their levels of development. Although Brazilian inequality is higher than in the US, its GDP per capita is much lower, at about one fourth of the US level. But inequality in America was at a similar level to inequality in Brazil today when it had a similar GDP per capita; for instance, Plotnick et al. (1998) estimate the Gini for the US in monetary gross income terms to be around 0.55 in 1940, roughly the same level as in Brazil today. Furthermore, the levels of inequality in the two countries are getting closer, with inequality declining in Brazil over the last decade (Lustig et al., 2013b) and persistently rising in the US (Kenworthy and Smeeding, forthcoming).

The two nations also have other similarities which can be noted. They have low intergenerational mobility (Jäntti et al., 2006, Corak, 2013) and high equality of opportunity (Brunori et al., 2013). More obviously, they are both are relatively large, western hemisphere nations with substantial interregional inequality and large racial and ethnic minorities. The unequal distribution of human capital across races is an important determinant of income inequality in both countries (Card and Krueger, 1992, Nopo, 2012).

So how well does each nation do in terms of reducing market income inequality, once we account for the incidence of almost all government social spending and taxes? The pre-fisc (market income) Gini in the United States is 0.448 and in Brazil it is 0.551. In the US it is reduced by 6.9 percentage points by direct transfers, indirect subsidies, and direct and indirect taxes, but by only 4.2 percentage points in Brazil. Neither nation is high on the list of OECD nations in inequality reduction through the fiscal system (Immervoll and Richardson, 2013, Joumard et al., forthcoming), which explains in part the high poverty rates in both countries (Morelli et al., forthcoming).

Public spending on health and education is larger than on cash and near cash transfers in both countries. When we add public spending on health and education to income, the decline in the Gini coefficients are almost identical in both countries. These results must be analyzed with some caveats in mind: specifically, that inequality reduction may be inflated if middle and upper class citizens opt out of the public education and health sectors, and that spending amounts do not reflect quality

\footnotetext{
${ }^{25}$ Poverty is defined as living in a household with household per capita income less than \$4 PPP per day.
} 
(which comes into play in both the US with respect to inflated health care costs and in Brazil with respect to low quality services).

In the United States, the market income Gini coefficient declines by 11.6 percentage points when direct cash and food transfers, housing and energy subsidies, individual and corporate income taxes, property taxes, expenditure taxes, and public spending on health (Medicare and Medicaid) and education (public primary and secondary school, Head Start, and public daycare through CCDF and TANF) are included in the income concept. When contributory pensions are counted as a government transfer, the Gini declines by 15.8 percentage points.

In Brazil, the Gini coefficient is reduced by 11.9 percentage points when we include all of these components in income, where health spending is in the form of free care received at public health facilities and education spending is in the form of public primary and secondary school, public preschool, and free public daycare for low income families. When pensions are considered a transfer, the Gini declines by 13.9 percentage points. The conclusions from our comparison are robust to other adjustments for family size (Appendix $\mathrm{A}$ in the online supplement).

The lessons from this exercise are instructive. Transfers that maintain consumption are usually in cash or near cash terms. Transfers that can be seen as investments in human capital (health and education) are most often in-kind. In the United States the systems are separate, but generally targeted to the poor. In Brazil, the relatively massive Bolsa Famillia delivers both consumption (to families) and education and healthcare to their children, in a well-targeted program. Some have argued that the United States ought to consider a similar program; conditional cash transfer programs modeled after Bolsa Família and Mexico's Oportunidades have in fact been piloted in New York City, Memphis, and the Bronx-their expansion at the national level could prove to be an important redistributive instrument.

Meanwhile, Brazil could benefit from higher quality schools and healthcare (though not at US prices). In addition, now that Brazil's extreme poor are almost universally covered by at least one cash transfer program (Lustig et al., 2013a), the country might consider incentivizing formality through refundable tax credits. The EITC has been shown to increase labor force participation (Eissa and Liebman, 1996) and increase intergenerational mobility (Chetty et al., 2013), perhaps because recipients use a portion of the benefits for expenses that help improve economic and social mobility (Smeeding et al., 2000). Brazil might also consider implementing a targeted large-scale food assistance program like SNAP, which is the United States' most effective anti-poverty program for the non-elderly (Tiehan et al., 2013). Furthermore, both EITC and SNAP were exceptionally responsive to the recession (Immervoll and Richardson, 2013, Ziliak, 2013), and had an increasing impact on poverty reduction between 2011 and 2012 (Short, 2013).

Perhaps each country could benefit by mimicking the best aspects of the social spending and taxation systems in the other country. Nevertheless, we would rather suggest that both countries look at the way that other large nations such as Australia and Canada finance and deliver public services with better and more pro-poor redistribution, more equality, and more mobility. 


\section{REFERENCES}

Aaberge, R., A. Björklund, M. Jäntti, M. Palme, P. J. Pedersen, N. Smith, and T. Wennemo, "Income Inequality and Income Mobility in the Scandinavian Countries Compared to the United States," Review of Income and Wealth 48, 443-469, 2002.

Aaronson, D. and B. Mazumder, "Intergenerational Economic Mobility in the United States, 1940 to 2000" Journal of Human Resources, 43(1), 139—172, 2008.

Alm, J. and E.B. Sennoga, "Mobility, Competition, and the Distributional Effects of Tax Evasion," National Tax Journal, 63 (4), 1055-1084, 2010.

Alm, J. and K. Finlay, "Who Benefits from Tax Evasion?”, Economic Analysis and Policy, 43(2), 139_ 154, 2013.

Alm, J., R. Bahl, and M.N. Murray, "Tax Structure and Tax Compliance," Review of Economics and Statistics, 72(4), 603-613, 1990.

Alvaredo, F. and L. Gasparini, "Recent Trends in Inequality and Poverty in Developing Countries," in A.B. Atkinson and F. Bourguignon, eds., Handbook of Income Distribution, vol. 2, Elsevier, Amsterdam, forthcoming.

Anderson, G.F., U.E. Reinhardt, P.S. Hussey, and V. Petrosyan, "It's the Prices, Stupid: Why the United States is so Different from Other Countries," Health Affairs, 22, 89-105, 2003.

Atkinson, A.B. and S. Morelli, "Chartbook of Economic Inequality: 25 Countries," Institute for New Economic Thinking Research Note 015, 2012.

Atkinson, A.B., L. Rainwater, and T.M. Smeeding, "Income Distribution in OECD Countries: Evidence from the Luxembourg Income Study (LIS)," Social Policy Studies No. 18, Organization for Economic Cooperation and Development, Paris, 1995.

Auerbach, A.J., "Who Bears the Corporate Tax? A Review of What We Know," In J.M. Poterba, ed., Tax Policy and the Economy, volume 20, MIT Press, Cambridge, 2006.

Borjas, G.J., "The Wage Structure and the Sorting of Workers in the Public Sector," Working Paper 9313, National Bureau of Economic Research, Cambridge, 2002.

Bosch, M. and R. Campos, "The Trade-offs of Social Assistance Programs in the Labor Market: the Case of the Seguro Popular Program in Mexico," Centro de Estudios Económicos Working Paper 2010-12, Colegio de México, Mexico City, 2010.

Bourguignon, F., F.H.G. Ferreira, and M. Menéndez, "Inequality of Opportunity in Brazil," Review of Income and Wealth, 53(4), 585-618, 2007.

Bourguignon, F., F.H.G. Ferreira, and P. G. Leite, "Beyond Oaxaca-Blinder: Accounting for Differences in Household Income Distributions," Journal of Economic Inequality, 6, 117-148, 2008. 
Bradbury, B., "The Fourth Retirement Pillar in Rich Countries," in J. C. Gornick and M. Jäntti, eds., Income Inequality: Income Disparities and the Middle Class in Affluent Countries, Stanford University Press, California, 2013.

Braga, B., S. Firpo, and G. Gonzaga, "Escolaridade e o Diferencial de Rendimentos entre o Setor Privado e o Setor Público no Brasil,” Pesquisa e Planejamento Econômico, 39, 431-464, 2009.

Brunori, P., F.H.G. Ferreira, and V. Peragine, "Inequality of Opportunity, Income Inequality and Economic Mobility: Some International Comparisons,” Discussion Paper 7155, Institute or the Study of Labor (IZA), Bonn, 2013.

Bucheli, M., N. Lustig, M. Rossi, and F. Amábile, "Social Spending, Taxes and Income Redistribution in Uruguay," Public Finance Review, forthcoming.

Buhmann, B., L. Rainwater, G. Schmauss, and T.M. Smeeding, "Equivalence Scales, Well-being, Inequality, and Poverty: Sensitivity Estimates Across Ten Countries using the Luxembourg Income Study Database," Review of Income and Wealth, 34, 115-142, 1988.

Bureau of Economic Analysis, U.S. Economic Accounts, 2013 (http://www.bea.gov/).

Cabrera, M., N. Lustig, and H.E. Morán, "Fiscal Policy and the Ethnic Divide in Guatemala," Commitment to Equity (CEQ), New Orleans, 2013.

Callan, T., T.M. Smeeding, and P. Tsakloglou, "Short-Run Distributional Effects of Public Education Transfers to Tertiary Education Students in Seven European Countries," Education Economics, 16(3), 275-288, 2008.

Camacho, A., E. Conover, and A. Hoyos, "Effects of Colombia's Social Protection System on Workers' Choice between Formal and Informal Employment," Policy Research Working Paper 6564, World Bank, Washington, D.C., 2013.

Capeau, B., A. Decoster, and D. Phillips, "Consumption and Indirect Tax Microsimulation,” in C. O’Donoghue, ed., Handbook of Microsimulation, forthcoming.

Card, D. and A.B. Krueger, "School Quality and Black-White Relative Earnings: A Direct Assessment," Quarterly Journal of Economics, 107, 151-200, 1992.

CEDLAS (Centro de Estudios Distributivos, Laborales y Sociales) and the World Bank, SocioEconomic Database for Latin America and the Caribbean, 2013 (http://sedlac.econo.unlp.edu.ar/).

Chetty, R., N. Hendren, P. Kline, and E. Saez, “The Economic Impacts of Tax Expenditures: Evidence from Spatial Variation across the U.S.," mimeo, 2013 (http://obs.rc.fas.harvard.edu/chetty/tax_expenditure_soi_whitepaper.pdf).

Congressional Budget Office, “The 2013 Long-Term Budget Outlook," 2013 (http://www.cbo.gov/sites/default/files/cbofiles/attachments/44521-LTBO-

1Column_0.pdf).

Contreras, D. and J. Ruiz-Tagle, "CEQ Master Workbook: Chile," Commitment to Equity (CEQ), New Orleans, 2013. 
Corak, M., "Inequality from Generation to Generation: the United States in Comparison,"

Graduate School of Public and International Affairs Working Paper, University of Ottawa, Ottawa, 2011 (http://milescorak.files.wordpress.com/2012/01/inequality-from-generationto-generation-the-united-states-in-comparison-v3.pdf).

, "Income Inequality, Equality of Opportunity, and Intergenerational Mobility," Journal of Economic Perspectives 27, 79-102, 2013.

Corbacho, A., V.F. Cibils, and E. Lora, More than Revenue: Taxation as a Development Tool, Palgrave Macmillan, New York, 2013.

Davidson, R. and J.-Y. Duclos, "Statistical Inference for the Measurement of the Incidence of Taxes and Transfers," Econometrica, 65, 1453-1465, 1997.

Denk, O., R. Hagemann, P. Lenain, and V. Somma, "Inequality and Poverty in the United States: Public Policies for Inclusive Growth,” Economics Department Working Paper, Organisation for Economic Co-operation and Development (OECD), Paris, 2013.

Eissa, N. and J.B. Liebman, "Labor Supply Response to the Earned Inccome Tax Credit," Quarterly Journal of Economics, 112, 605-637, 1996.

Engel, E.M.R.A., A. Galetovic, and C.E. Raddatz, "Taxes and Income Redistribution in Chile: Some Unpleasant Redistributive Arithmetic," Journal of Development Economics, 59, 155-192, 1999.

Ferreira, F.H.G., and J. Gignoux, "The Measurement of Inequality of Opportunity: Theory and an Application to Latin America," Review of Income and Wealth, 57, 622-657, 2011.

Ferreira, F.H.G., P.G. Leite, and J.A. Litchfield, “The Rise and Fall of Brazilian Inequality: 19812004," Macroeconomic Dynamics, 12, 199_230, 2008.

Ferreira, F.H.G., P.G. Leite, and M. Ravallion, "Poverty Reduction without Economic Growth? Explaining Brazil's Poverty Dynamics, 1985-2004," Journal of Development Economics, 93, 20 36, 2010.

Ferreira, F.H.G., J. Messina, J. Rigolini, L.F. López-Calva, M. Ana Lugo, and R. Vakis, Economic Mobility and the Rise of the Latin American Middle Class, World Bank, Washington, DC, 2013.

Garfinkel, I., L. Rainwater, and T.M. Smeeding, "A Re-examination of Welfare States and Inequality in Rich Nations: How In-kind Transfers and Indirect Taxes Change the Story," Journal of Policy Analysis and Management, 25(4), 897-919, 2006.

Garganta, S. and L. Gasparini, "El Impacto de un Programa Social Sobre la Informalidad Laboral: el Caso de la AUH de Argentina," CEDLAS Working Paper 133, CEDLAS, La Plata, Argentina, 2012.

Goñi, E., J.H. López, and L. Servén, "Fiscal Redistribution and Income Inequality in Latin America,” World Development, 39, 1558-1569, 2011.

Goldin, C., and L. Katz, The Race Between Education and Technology, Harvard University Press, Cambridge, 2008. 
Heckman, J.J., “Schools, Skills, and Synapses,” Economic Inquiry, 46(3), 289-324, 2008.

"Effective Child Development Strategies," in Zigler, E., W.S. Gilliam, and W.S. Barnett, eds., The Pre-K Debates: Current Controversies and Issues, Paul H. Brookes Publishing Co., Baltimore, 2011.

Higgins, S., N. Lustig, J. Ramirez, and B. Swanson, "Social Spending, Taxes and Income Redistribution in Paraguay," Working Paper 11, Commitment to Equity (CEQ), New Orleans, 2013.

Higgins, S. and C. Pereira, "The Effects of Brazil's Taxation and Social Spending on the Distribution of Household Income," Public Finance Review, forthcoming.

Hines, Jr., J.R., and L. Summers, "How Globalization Affects Tax Design," in J.R. Brown and J.M. Poterba, eds., Tax Policy and the Economy, vol. 23, 123-157, University of Chicago Press, Chicago, 2009.

International Monetary Fund, "United States 2013 Article IV Consultation," Country Report 13/236, International Monetary Fund, Washington, D.C., 2013 (http://www.imf.org/external/pubs/ft/scr/2013/cr13236.pdf).

Immervoll, H., H. Levy, J.R.B. Nogueira, C. O’ Donoghue, and R. Bezerra, “The Impact of Brazil's Tax-benefit System on Inequality and Poverty," in S. Klasen and F. Nowak-Lehmann, eds., Poverty, Inequality, and Policy in Latin America, MIT Press, Cambridge, 2009.

Immervoll, H. and L. Richardson, "Redistribution Policy in Europe and the United States: Is the Great Recession a 'Game Changer' for Working-age Families?” Social, Employment and Migration Working Papers No. 150, OECD Publishing, Paris, 2013

(http://dx.doi.org/10.1787/5k44xwtc0txp-en).

Jäntti, M., K. Røed, R. Naylor, A. Björklund, B. Bratsberg, O. Raaum, E. Österbacka, and T. Eriksson, "American Exceptionalism in a New Light: A Comparison of Intergenerational Earnings Mobility in the Nordic Countries, the United Kingdom, and the United States," Discussion Paper 1938, Institute for the Study of Labor (IZA), Bonn, 2006.

Jaramillo, M., "The Incidene of Social Spending and Taxes in Peru," Public Finance Review, forthcoming.

Johnson, D. and T. Smeeding, "Inequality Measurement," in J. Wright, ed., International Encyclopedia of Social and Behavioral Sciences, 2nd edition, Elsevier Ltd., Oxford, forthcoming.

Joumard, I., M. Pisu and D. Bloch, "Tackling Income Inequality: The Role of Taxes and Transfers," OECD Journal: Economic Studies, forthcoming.

Kakwani, N.C., "Measurement of Tax Progressivity: an International Comparison," The Economic Journal, 87, 71-80, 1977. 
Kenworthy, L., "Has Rising Inequality Reduced Middle-Class Income Growth?” in J.C. Gornick and M. Jäntti, eds., Income Inequality: Economic Disparities and the Middle Class in Affluent Countries, 101-114, Stanford University Press, Palo Alto, 2013.

Kenworthy, L. and T. Smeeding, "The United States: High and Rapidly-Rising Inequality," in B. Nolan and W. Salverda, eds., Inequality and Its Impacts, volume 2, Oxford University Press, Oxford, forthcoming.

Kim, K. and P.J. Lambert, "Redistributive Effect of U.S. Taxes and Public Transfers, 1994-2004," Public Finance Review, 37, 3-26, 2009.

Lambert, P.J., The Distribution and Redistribution of Income, 3rd edition, Manchester University Press, Manchester, 2001.

, "On the Redistributive Effect of Taxes and Benefits," Scottish Journal of Political Economy, 32, 39-54, 1985.

Levy, S. and N. Schady, "Latin America’s Social Policy Challenge: Education, Social Insurance, Redistribution," Journal of Economic Perspectives, 27, 193-218, 2013.

LIS, Inequality and Poverty Key Figures, 2013 (http://www.lisdatacenter.org/data-access/keyfigures/inequality-and-poverty/).

Litschig, S. and K.M. Morrison, "The Impact of Intergovernmental Transfers on Education Outcomes and Poverty Reduction," American Economic Journal: Applied Economics, 5, 206-240, 2013.

Lora, E. and J. Fajardo, "Employment and Taxes in Latin America: an Empirical Study of the Effects of Payroll, Corporate Income and Value-added Taxes on Labor Outcomes," Working Paper IDB-WP-334, Inter-American Development Bank, Washington, D.C., 2012a.

, “Hay un Sesgo Anti-laboral en los Impuestos en América Latina?”, Resumen de Políticas IDB-PB-177, Inter-American Development Bank, Washington, D.C., 2012b.

Lustig, N. and S. Higgins, "Commitment to Equity (CEQ): Estimating the Incidence of Social Spending, Subsidies, and Taxes Handbook," CEQ Working Paper No. 1, 2013 (http://www.commitmentoequity.org/publications_files/Methodology/CEQWPNo1\%20H andbook $\% 20$ Edition $\% 20 \operatorname{Sept}^{2} \% 202013$.pdf).

Lustig, N. and C. Pessino, "Social Spending and Income Redistribution in Argentina during the 2000s: the Increasing Role of Noncontributory Pensions," Public Finance Review, forthcoming.

Lustig, N., C. Pessino, and J. Scott, "The Impact of Taxes and Social Spending on Inequality and Poverty in Argentina, Bolivia, Brazil, Mexico, Peru and Uruguay," Public Finance Review, forthcoming.

Lustig, N., F. Amábile, M. Bucheli, G. Gray Molina, S. Higgins, M. Jaramillo, W. Jiménez Pozo, V. Paz Arauco, C. Pereira, M. Rossi, J. Scott, and E. Yáñez Aguilar, “The Impact of Taxes and 
Social Spending on Inequaltiy and Poverty in Argentina, Bolivia, Brazil, Mexico, Peru and Uruguay: an Overview," Working Paper No. 13, Commitment to Equity (CEQ), New Orleans, 2013a.

Lustig, N., L.F. López-Calva, and E. Ortiz-Juárez, "Declining inequlaity in Latin America in the 2000s: The cases of Argentina, Brazil, and Mexico," World Development, 44(1): 129-141, 2013b.

Medeiros, M. and P.H.G.F. Souza, "The State and Income Inequality in Brazil," Institute for Research on Labor and Employment Working Paper, University of California at Berkeley, Berkeley, 2013.

Melendez, M., “CEQ Master Workbook: Colombia,” Commitment to Equity (CEQ), 2013.

Milanović, B., 'Determinants of Cross-Country Income Inequality: An 'Augmented' Kuznets' Hypothesis," Policy Research Working Paper 1246, World Bank, Washington, D.C., 1994.

Ministério da Fazenda, Balanço do Setor Público Nacional: Exercício de 2009, 2010a (http://www3.tesouro.gov.br/contabilidade_governamental/downloads/Balanco_Setor_pu blico_Nacional.pdf).

C Carga Tributária no Brasil 2009, 2010b (http://www.receita.fazenda.gov.br/Publico/estudoTributarios/estatisticas/CTB2009.pdf).

Morelli, S., J. Thompson, and T.M. Smeeding, "Post-1970 Trends in Within-Country Inequality and Poverty," in A. Atkinson and F. Bourguignon, eds., Handbook of Income Distribution, vol. 2, forthcoming.

Newman, K. and R. O'Brien, Taxing the Poor: Doing Damage to the Truly Disadvantaged, University of California Press, Berkeley, 2011.

Nogueira, J.R.B., R. Bezerra, and E.S. de Souza, “A Brazilian Tax-benefit Microsimulation Model,” in C.M. Urzúa, ed., Microsimulation Models for Latin America, 19-50, International Development Research Center and United Nations Development Programme and Tecnológico de Monterrey, Mexico City, 2011.

Nopo, Hugo, New Century, Old Disparities: Gender and Ethnic Earnings Gaps in Latin America and the Caribbean, Inter-American Development Bank and World Bank, Washington, D.C., 2012.

OECD (Organisation for Economic Co-operation and Development), Divided We Stand: Why Inequality Keeps Rising, OECD Publishing, Paris, 2011a.

, Strong Performers and Successful Reformers in Education: Lessons from PISA for the United States, OECD Publishing, Paris, 2011b.

, “PISA 2009 Results: Executive Summary,” OECD Publishing, Paris, 2010.

Paes de Barros, R., F.H.G. Ferrira, J. Molinas Vega, J. Saavedra, "Measuring Inequality of Opportunities in Latin America and the Caribbean," World Bank, Washington, D.C., 2009. 
Paes de Barros, R., M. de Carvalho, S. Franco, and R. Mendonça, "Markets, the State, and the Dynamics of Inequality in Brazil," in L.F. López-Calva and N. Lustig, eds., Declining Inequality in Latin America: a Decade of Progress?, 134-174, Brookings Institution Press, Washington, D.C., 2010.

Paz Arauco, V., G. Gray Molina, W. Jiménez Pozo, and E. Yáñez Aguilar, "Explaining Low Redistributive Impact in Bolivia," Public Finance Review, forthcoming.

Pistolesi, N., "Inequality of Opportunity in the Land of Opportunities, 1968-2001," Journal of Economic Inequality, 7, 411-433, 2009.

Plotnick, R., E. Smolensky, E. Evenhouse and S. Reilly, "Inequality, Poverty, and the Fisc in Twentieth-century America," Journal of Post Keynesian Economics, 21, 51-75, 1998.

Poterba, J.M., "Lifetime Incidence and the Distributional Burden of Excise Taxes," American Economic Review Papers and Proceedings 79, 325-330, 1989.

Poterba, J.M. and K.S. Rueben, "The Distribution of Public Sector Wage Premia: New Evidence using Quantile Regression Methods," Working Paper 4734, National Bureau of Economic Research, Cambridge, 1994.

Roemer, J., "Economic Development as Opportunity Equalization." World Bank Economic Review, forthcoming.

Sauma, P. and J.D. Trejos, "CEQ Master Workbook: Costa Rica," Commitment to Equity (CEQ), 2013.

Scott, J., "Redistributive Impact and Efficiency of Mexico's Fiscal System," Public Finance Review, forthcoming.

Short, K., The Research Supplemental Poverty Measure: 2012, U.S. Census Bureau, Washington, D.C., 2013 (http://www.census.gov/prod/2013pubs/p60-247.pdf).

Short, K. and A. O'Hara, "Valuing Housing in Measures of Household and Family Economic WellBeing," prepared for the Annual Meeting of the Allied Social Sciences Associations, 2008 (http://www.census.gov/housing/ahs/files/valuing_housing.pdf).

Smeeding, T.M., K.R. Phillips, and M. O’Conner, “The EITC: Expectation, Knowledge, Use, and Economic and Social Mobility," National Tax Journal, 53, 1187-1210, 2000.

Soares, F.V., S. Soares, M. Medeiros, and R.G. Osório, "Programas de Transferência de Renda no Brasil: Impactos sobre a Desigualdade," in R. Paes de Barros, M.N. Foguel, and G. Ulyssea, eds., Desigualdade de Renda no Brasil: uma Análise da Queda Recente, volume 2, 87-129, Instituto de Pesquisa Econômica Aplicada, Brasilia, 2007.

Souza, P.H.G.F. and M. Medeiros, "The Decline in Inequality in Brazil, 2003-2009: the Role of the State," Institute for Research on Labor and Employment Working Paper, University of California at Berkeley, Berkeley, 2013. 
Tax Foundation, "Trend \#4: Sales Tax Increases," Tax Foundation Fiscal Fact No. 310, 2012 (http://taxfoundation.org/article/trend-4-sales-tax-increases).

Thompson, J. and T. Smeeding, "Inequality and Poverty in the United States: the Aftermath of the Great Recession," Finance and Economics Discussion Series 2013-51, Federal Reserve Board, Washington, D.C., 2013.

Tiehen, L., D. Jolliffe, and T. Smeeding. "The Effect of SNAP on Poverty," presented at the Association for Policy Analysis and Management Annual Research Conference, 2013 (https://appam.confex.com/data/extendedabstract/appam/2013/Paper_7629_extendedabs tract_457_0.pdf).

US Census Bureau, "Historical National Population Estimates: July 1, 1900 to July 1, 1999,” 2000 (http://www.census.gov/popest/data/national/totals/pre-1980/tables/popclockest.txt).

Wallace, S., M. Wasylenko, and D. Weiner, "The distributional implications of the 1986 tax reform," National Tax Journal, 44, 181-198, 1991.

World Bank., World DataBank, 2013 (http://databank.worldbank.org/data/home.aspx).

Ziliak, J.P., "Why Are So Many Americans on Food Stamps? The Role of the Economy, Policy, and Demographics," presented at the Association for Policy Analysis and Management Annual Research Conference, 2013 (http://gatton.uky.edu/Faculty/Ziliak/Ziliak_SNAP_100413.pdf). 


\section{CEQ WORKING PAPER SERIES}

\section{WORKING PAPER NO. 1}

Lustig, Nora and Sean Higgins. 2013. Commitment to Equity Assessment (CEQ): Estimating the Incidence of Social Spending, Subsidies and Taxes. Handbook. CEQ Working Paper No. 1, Center for Inter-American Policy and Research and Department of Economics, Tulane University and Inter-American Dialogue, January.

\section{WORKING PAPER NO. 2}

Lustig, Nora. 2012. Commitment to Equity: Diagnostic Questionnaire. CEQ Working Paper No. 2, Center for Inter-American Policy and Research and Department of Economics, Tulane University and InterAmerican Dialogue, August.

WORKING PAPER NO. 3

Lustig, Nora and George Gray Molina, Sean Higgins, Miguel Jaramillo, Wilson Jiménez, Veronica Paz, Claudiney Pereira, Carola Pessino, John Scott, and Ernesto Yañez. 2012. The Impact of Taxes and Social Spending on Inequality and Poverty in Argentina, Bolivia,Brazil, Mexico and Peru: A Synthesis of Results. CEQ Working Paper No. 3, Center for Inter-American Policy and Research and Department of Economics, Tulane University and Inter-American Dialogue, August.

WORKING PAPER NO. 4

Lustig, Nora and Sean Higgins. 2012. Fiscal Incidence, Fiscal Mobility and the Poor: A New Approach. CEQ Working Paper No. 4, Center for Inter-American Policy and Research and Department of Economics, Tulane University and Inter-American Dialogue, September.

WORKING PAPER NO. 5

Lustig, Nora and Carola Pessino. 2013. Social Spending and Income Redistribution in Argentina in the 2000s: the Rising Role of Noncontributory Pensions. CEQ Working Paper No. 5, Center for Inter-American Policy and Research and Department of Economics, Tulane University and Inter-American Dialogue, REVISED July 2013.

WORKING PAPER NO. 6

Paz Arauco, Verónica, George Gray Molina, Wilson Jiménez Pozo, and Ernesto Yáñez Aguilar. 2013. Explaining Low Redistributive Impact in Bolivia. CEQ Working Paper No. 6, Center for Inter-American Policy and Research and Department of Economics, Tulane University and Inter-American Dialogue, January.

WORKING PAPER NO. 7

Higgins, Sean and Claudiney Pereira. 2013. The Effects of Brazil's High Taxation and Social Spending on the Distribution of Household Income. CEQ Working Paper No. 7, Center for Inter-American Policy and Research and Department of Economics, Tulane University and Inter-American Dialogue, January.

WORKING PAPER NO. 8

Scott, John. 2013. Redistributive Impact and Efficiency of Mexico's Fiscal System. CEQ Working Paper No. 8, Center for Inter-American Policy and Research and Department of Economics, Tulane University and Inter-American Dialogue, January.

WORKING PAPER NO. 9

Jaramillo Baanante, Miguel. 2013. The Incidence of Social Spending and Taxes in Peru. CEQ Working Paper No. 9, Center for Inter-American Policy and Research and Department of Economics, Tulane University and Inter-American Dialogue, January.

WORKING PAPER NO. 10

Bucheli, Marisa and Nora Lustig, Máximo Rossi and Florencia Amábile. 2013. Social Spending, Taxes, and Income Redistribution in Uruguay. CEQ Working Paper No. 10, Center for Inter-American Policy and Research and Department of Economics, Tulane University and Inter-American Dialogue, January. 
WORKING PAPER NO. 11

Higgins, Sean and Nora Lustig, Julio Ramirez and Billy Swanson. Social Spending, Taxes and Income Redistribution in Paraguay. CEQ Working Paper No. 11, Center for Inter-American Policy and Research and Department of Economics, Tulane University and Inter-American Dialogue, February.

WORKING PAPER NO. 12

Alvaredo, Facundo and Juliana Londoño Vélez. 2013. High Incomes and Personal Taxation in a Developing Economy: Colombia 1993-2010. CEQ Working Paper No. 12, Center for Inter-American Policy and Research and Department of Economics, Tulane University and Inter-American Dialogue, March.

WORKING PAPER NO. 13

Lustig, Nora, and Carola Pessino and John Scott. 2013. The Impact of Taxes and Social Spending on Inequality and Poverty in Argentina, Bolivia, Brazil, Mexico, Peru and Uruguay: An Overview. CEQ Working Paper No. 13, Center for Inter-American Policy and Research and Department of Economics, Tulane University and Inter-American Dialogue, April.

WORKING PAPER NO. 14

Higgins, Sean and Nora Lustig. 2013. Measuring Impoverishment: An Overlooked Dimension of Fiscal Incidence. CEQ Working Paper No. 14, Center for Inter-American Policy and Research and Department of Economics, Tulane University and Inter-American Dialogue, April.

WORKING PAPER NO. 15

Tanzi, Vito. 2013. Tax Reform in Latin America: A long term assessment. CEQ Working Paper No. 15, Center for Inter-American Policy and Research and Department of Economics, Tulane University and InterAmerican Dialogue, April.

WORKING PAPER NO. 16

Higgins, Sean and Nora Lustig, Whitney Ruble and Timothy Smeeding. 2013. Comparing the Incidence of Taxes and Social Spending in Brazil and the United States. CEQ Working Paper No. 16, Center for Inter-American Policy and Research and Department of Economics, Tulane University and Inter-American Dialogue, November. 


\section{WHAT IS CEQ?}

Led by Nora Lustig (Tulane University) and Peter Hakim (Inter-American Dialogue), the Commitment to Equity (CEQ) project is designed to analyze the impact of taxes and social spending on inequality and poverty, and to provide a roadmap for governments, multilateral institutions, and nongovernmental organizations in their efforts to build more equitable societies. CEQ/Latin America is a joint project of the Inter-American Dialogue (IAD) and Tulane University's Center for Inter-American Policy and Research (CIPR) and Department of Economics. The project has received financial support from the Canadian International Development Agency (CIDA), the Development Bank of Latin America (CAF), the General Electric Foundation, the Inter-American Development Bank (IADB), the International Fund for Agricultural Development (IFAD), the Norwegian Ministry of Foreign Affairs, the United Nations Development Programme's Regional Bureau for Latin America and the Caribbean (UNDP/RBLAC), and the World Bank. http://commitmenttoequity.org 